\title{
Visual Anthropology
}

\section{The First Ethnographic Documentary? Luiz Thomaz Reis, the Rondon Commission and the Making of Rituais e Festas Borôro (1917)}

\section{Sylvia Caiuby Novaes, Edgar Teodoro da Cunha \& Paul Henley}

To cite this article: Sylvia Caiuby Novaes, Edgar Teodoro da Cunha \& Paul Henley (2017) The First Ethnographic Documentary? Luiz Thomaz Reis, the Rondon Commission and the Making of Rituais e Festas Borôro (1917), Visual Anthropology, 30:2, 105-146, DOI: 10.1080/08949468.2017.1276383

To link to this article: https://doi.org/10.1080/08949468.2017.1276383

\section{Published online: 16 Feb 2017.}

\section{Submit your article to this journal ¿}

Џ Article views: 273

View Crossmark data \lceil

Citing articles: 1 View citing articles $\llbracket$ 


\title{
The First Ethnographic Documentary? Luiz Thomaz Reis, the Rondon Commission and the Making of Rituais e Festas Borôro (1917)
}

\author{
Sylvia Caiuby Novaes, Edgar Teodoro da Cunha and Paul Henley
}

\begin{abstract}
Although rarely mentioned in English-language texts, Rituais de Festas Borôro has long been acknowledged as a masterpiece of early ethnographic film in the French and Brazilian literature. Shot in 1916 by a Brazilian army officer, Luiz Thomaz Reis, and released in 1917, the film is mainly about the funeral ceremony of the Bororo, an indigenous people of Central Brazil. Here we contrast this work with other ethnographic films of the period and suggest that it has a strong claim to be seen as the first ethnographic documentary in the modern sense of the term. We also consider the political circumstances that led to the filming in this particular form, its status as an ethnographic account of the funeral, and its place in the personal filmography of Luiz Thomaz Reis.
\end{abstract}

\section{THE FIRST ETHNOGRAPHIC DOCUMENTARY}

This article concerns Rituais e Festas Borôro, a 30-minute film made in a longvanished Bororo indigenous community of some 350 people that was situated on the banks of the São Lourenço river, about 100 kilometers south of Cuiabá, the capital of Mato Grosso State, in Central Brazil [Figure 1]. Shot between July and October 1916, and released the following year, the film is mainly about the funeral of a Bororo woman. Its director and cameraman was a Brazilian army officer, Luiz Thomaz Reis (1879-1940). ${ }^{1}$ Although this film has long been acknowledged in the French and Brazilian literature [Jordan 1992: 200-201; Piault 2000: 41-42; Tacca 2001, 2002], it is rarely mentioned in English-language texts. We argue here not only that Rituais e Festas Borôro is an early masterwork of

Sylvia Cainby Novaes is Professor of Anthropology at the Universidade de São Paulo. She has done research among the Bororo for over 30 years and founded LISA (Laboratorio de Imagem e Som em Antropologia) in 1991 where she coordinates research in visual anthropology. Email: scaiuby@usp.br

EDGAR TEODORO DA CUNHA is Professor of Anthropology and a documentary filmmaker at the Universidade Estadual Paulista, where he coordinates research in visual anthropology and performance on themes including the Bororo, the indigenous image and ethnographic cinema. E-mail: edgar.cunha@fclar.unesp.br

PAUl HeNley is Professor of Visual Anthropology at the Granada Centre for Visual Anthropology, University of Manchester. He recently completed a three-year Leverhulme Trust research fellowship dedicated to the study of early ethnographic film. E-mail: paul.henley@manchester.ac.uk 


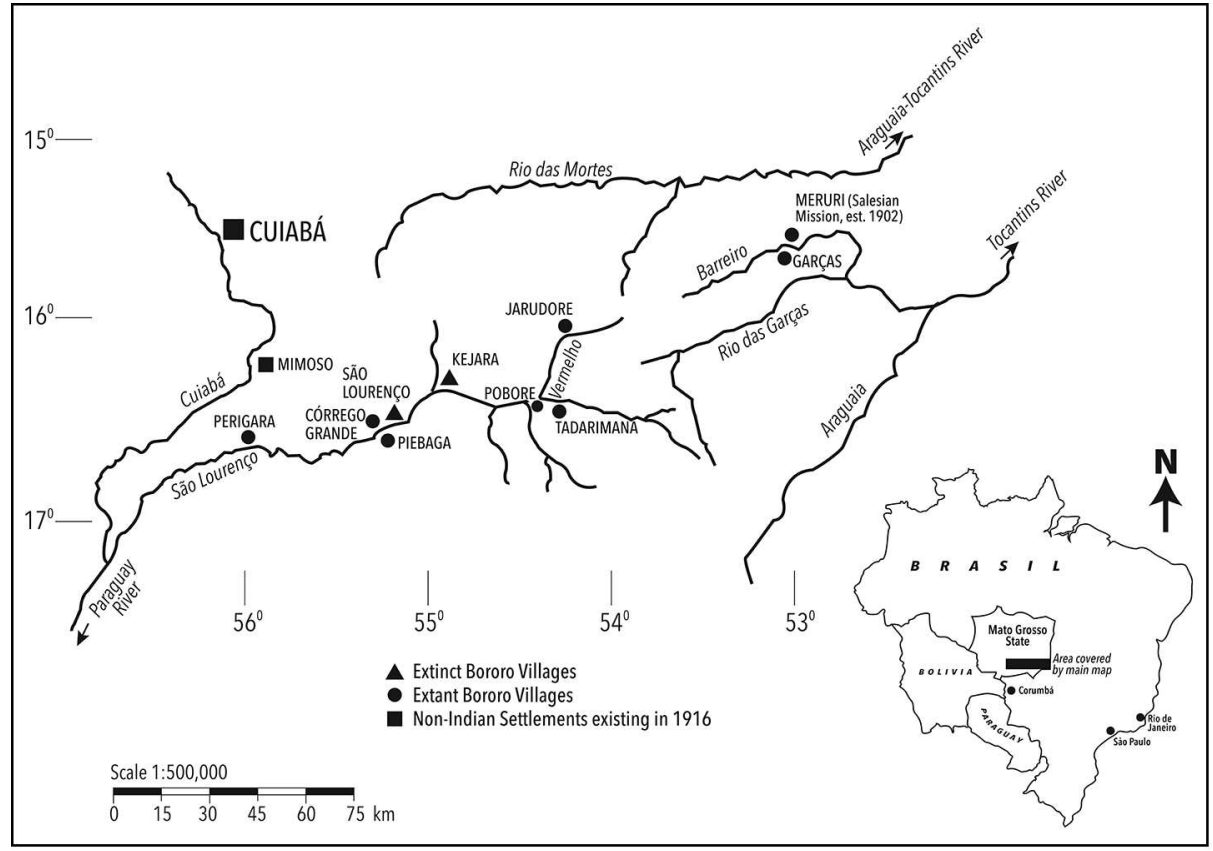

Figure 1 General map of the Bororo territory.

ethnographic cinema and, as such, deserves a higher profile in the Englishlanguage literature, but also that it has a strong claim to be considered the very first ethnographic documentary in the most widely used present-day sense of that much-contested term. ${ }^{2}$

The Bororo funeral is a highly complex ritual event that typically takes place over at least a month, and often longer, with many different aspects and phases. First described in German ethnographic literature by Karl von den Steinen in 1894, and then in Italian by the Salesian missionary Antonio Colbacchini in 1925 , it became more widely known about as a result of a brief account published in 1955 by Claude Lévi-Strauss in his celebrated travel memoir, Tristes Tropiques. ${ }^{3}$ This was based on the short visit that he made in the 1930s to the Bororo village of Kejara on the Rio Vermelho, only a few kilometers upstream from the community where Reis had shot his film some twenty years before [Figure 1]. Lévi-Strauss's then wife, Dina, also shot some shaky 8-mm footage of a Bororo funeral that has resurfaced relatively recently. ${ }^{4}$ However, the Bororo funeral only became a major focus of interest with the publication of an extended analysis in English by Jon Christopher Crocker in 1985. Since then, it has been the subject of a large number of further accounts, both textual and visual, including those by two of the authors of this article, Caiuby Novaes and Cunha. ${ }^{5}$

Yet despite all the attention focused upon the funeral in recent decades, it remains the case that in terms of the complexity of the ritual performances represented, as well as with regard to the sheer number of people involved, Reis's film offers the most elaborate visual account yet produced of this event. ${ }^{6}$ We will 
analyze below the circumstances through which this remarkable film came to be made, before assessing its value as a specifically ethnographic account of the Bororo funeral. We shall begin though by considering its status as a documentary film.

\section{RITUAIS E FESTAS BORÔRO AS A DOCUMENTARY FILM}

Surely, by the most conventional present-day norms, one would have little hesitation in classifying Rituais e Festas Borôro as a documentary, for it consists essentially of actuality footage shot over a some ten weeks that has been cut and re-ordered, at a ratio of about 2:1, to produce a film that in structural terms will be quite familiar to those who attend ethnographic film festivals even now, exactly a century later. The first third of the film, around ten minutes, offers scenes of a fishing expedition and various artisanal activities related directly or indirectly to the funeral, while it also introduces some of those who will play a leading part in the event [Figure $2 \mathrm{a}, 2 \mathrm{~b}$ ]. The remaining twenty minutes offer an abbreviated but still supposedly chronological account of the progress of the more ceremonial aspects of the funeral.

As presented, this ceremony consists of a series of dances in the village plaza, some collective, others involving just one or two individuals [Figure 2c, 2d]. The dances initially involve men only and are hidden from the women by a palm-leaf screen, but later the screen is removed and the dances become mixed. Although a number of the participants are wearing some items of European clothing, the great majority are wearing a more traditional form of dress, which in the case of men involves magnificent diadem-like headdresses and elaborate body painting but otherwise little else, while the women are mostly wearing simple wrap-around skirts, exposing the upper body. The women do not wear headdresses but many have handsome animal-teeth necklaces.

The dancing is interspersed with sequences of various related ritual events, including a form of competition between men who attempt to jump up and down while balancing on their heads large circular discs made of buriti palm leaves (known as mariddo), which can weigh up to $60 \mathrm{~kg}$ [Figure 2e]. There is also a scene in which the men withdraw to a secluded place outside the village for the aije ceremony, which Reis identifies as involving the enactment of a jaguar hunt, some men acting as hunters and others as jaguars. Shortly afterwards, they return to the village plaza and there is another dance, involving both men and women, both holding branches of leaves aloft. The film culminates in a striking sequence showing the burial of the deceased woman in a rolled-up mat, in a shallow grave in the plaza. The grave is surrounded by a semi-circular chorus of senior men, all wearing magnificent headdresses and energetically shaking large maracas. Meanwhile some women pour water over the corpse and then use hoes to cover it with earth [Figure 2f].

It was to be another decade before sound cinema emerged, so there is no soundtrack, nor even voice-over commentary, but there are numerous intertitles-38 of them over the course of 30 minutes - that fulfill much the same role as a voice-over might: that is, not only do they provide explanatory contexts, such as naming the 


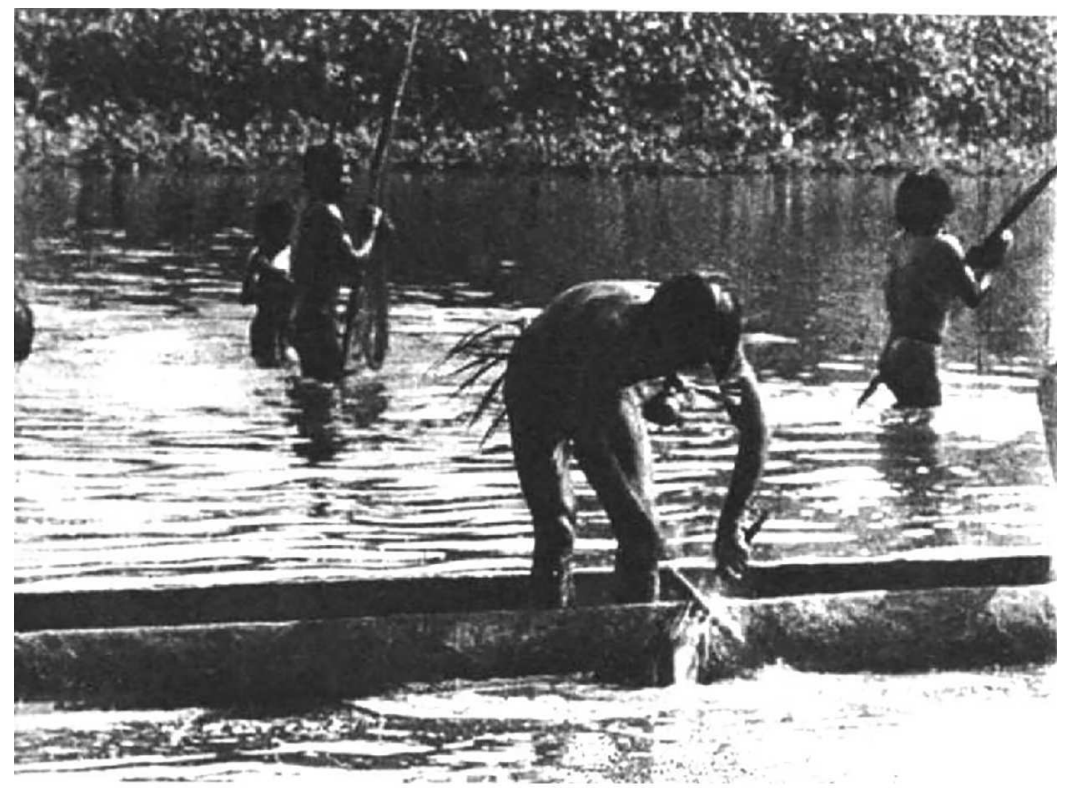

(a)

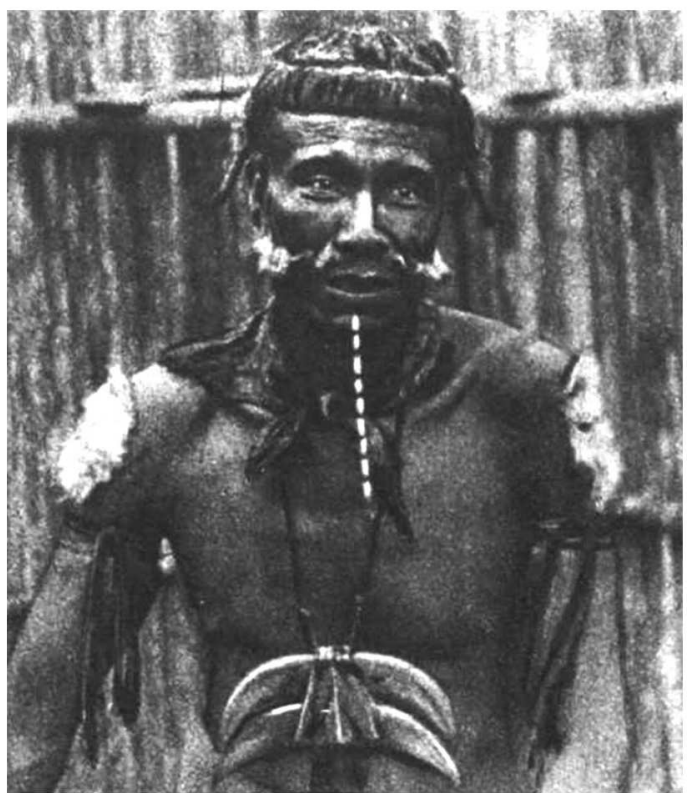

(b)

Figure 2 Scenes from Rituais e Festas Borôro. (a) Liana roots are beaten to release poison that will stun the fish (Rondon 1946: 250; (C) Acervo do Museo do Índio-FUNAI, Brazil). (b) A bari, a shaman, who will play a leading role in the dancing (Rondon 1946: 270; (C) Acervo do Museo do Índio-FUNAI, Brazil). (c) Some dances are collective (Rondon 1946: 263; (C) Acervo do Museo do Indio-FUNAI, Brazil). (d) Others involve only one or two performers as in this case, where two men wearing jaguar capes chant laments beside the corpse (Rondon 1946: 271; () Acervo do Museo do Indio-FUNAI, Brazil). (e) Men compete to jump with large mariddo discs on their heads (Rondon 1946: 280; (C) Acervo do Museo do Índio-FUNAI, Brazil). (f) In the final burial scene, the corpse is doused with water (Rondon 1946: 278; (c) Acervo do Museo do Índio-FUNAI, Brazil). 


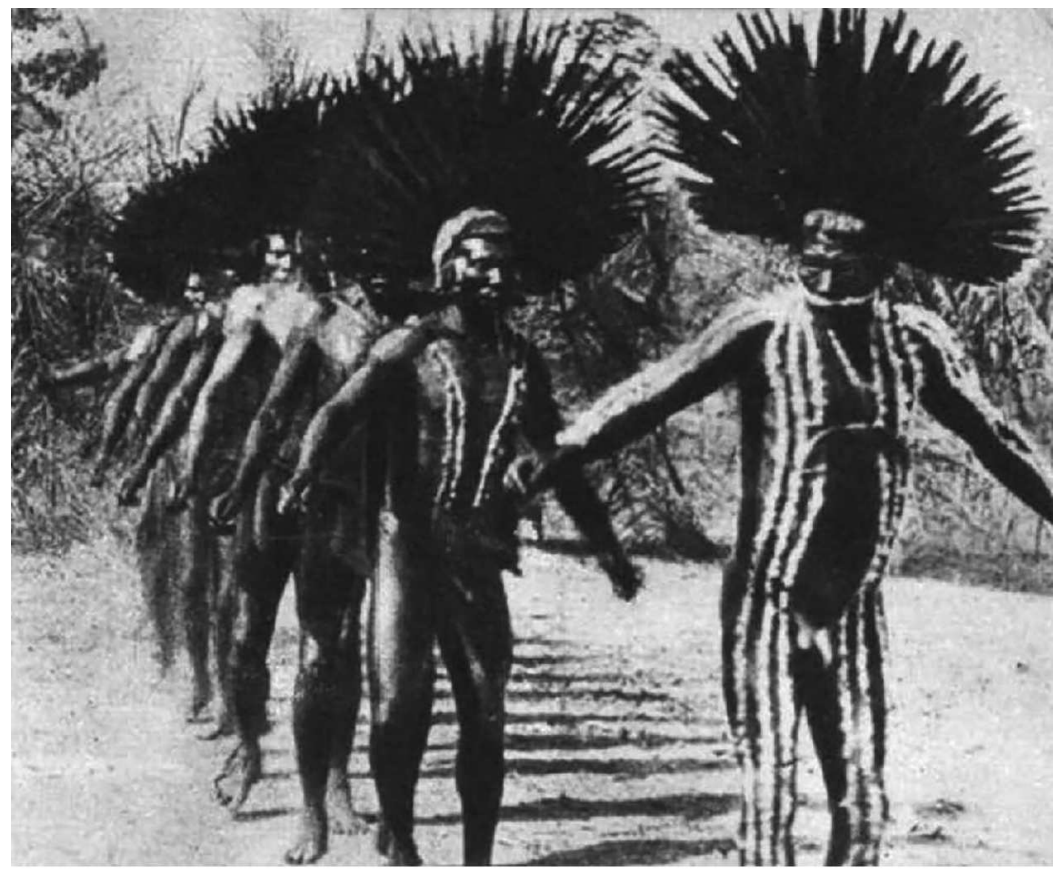

(c)

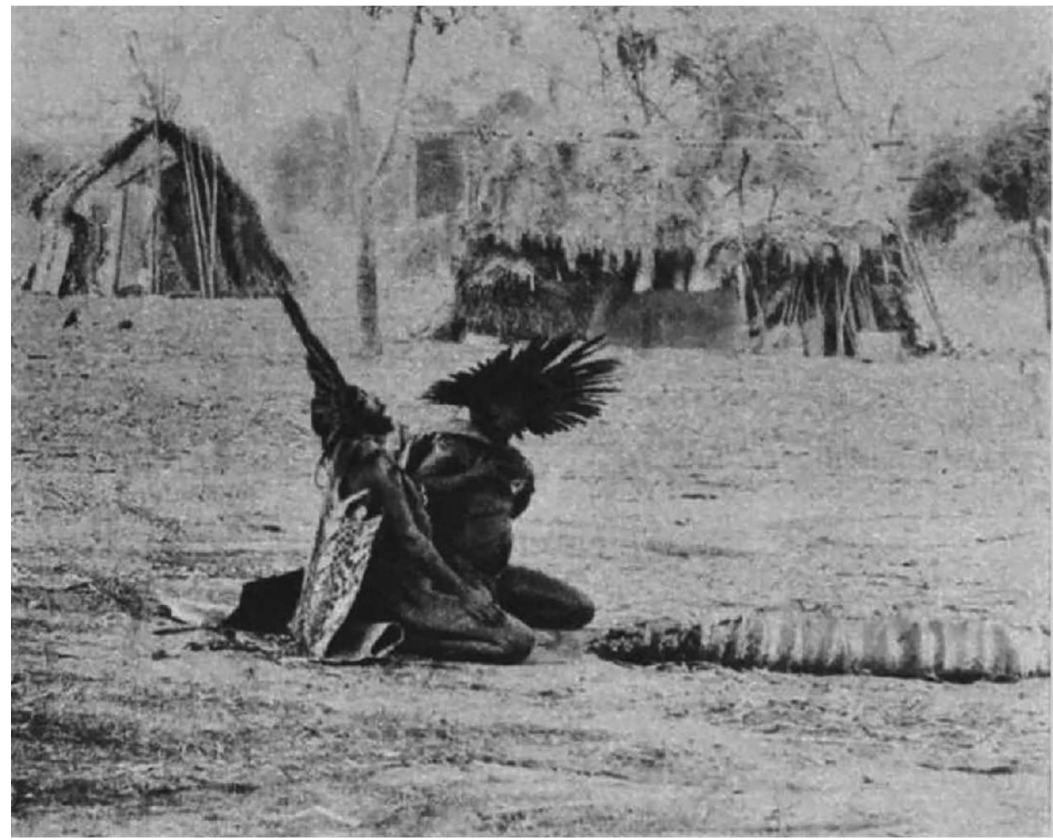

(d)

Figure 2 Continued. 


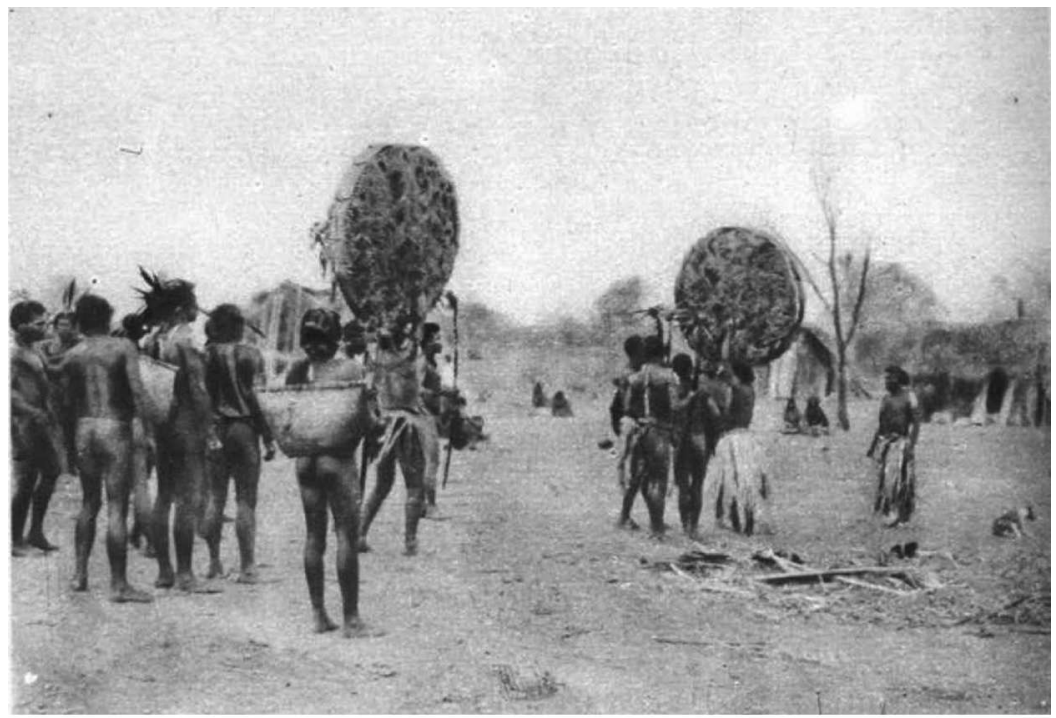

(e)

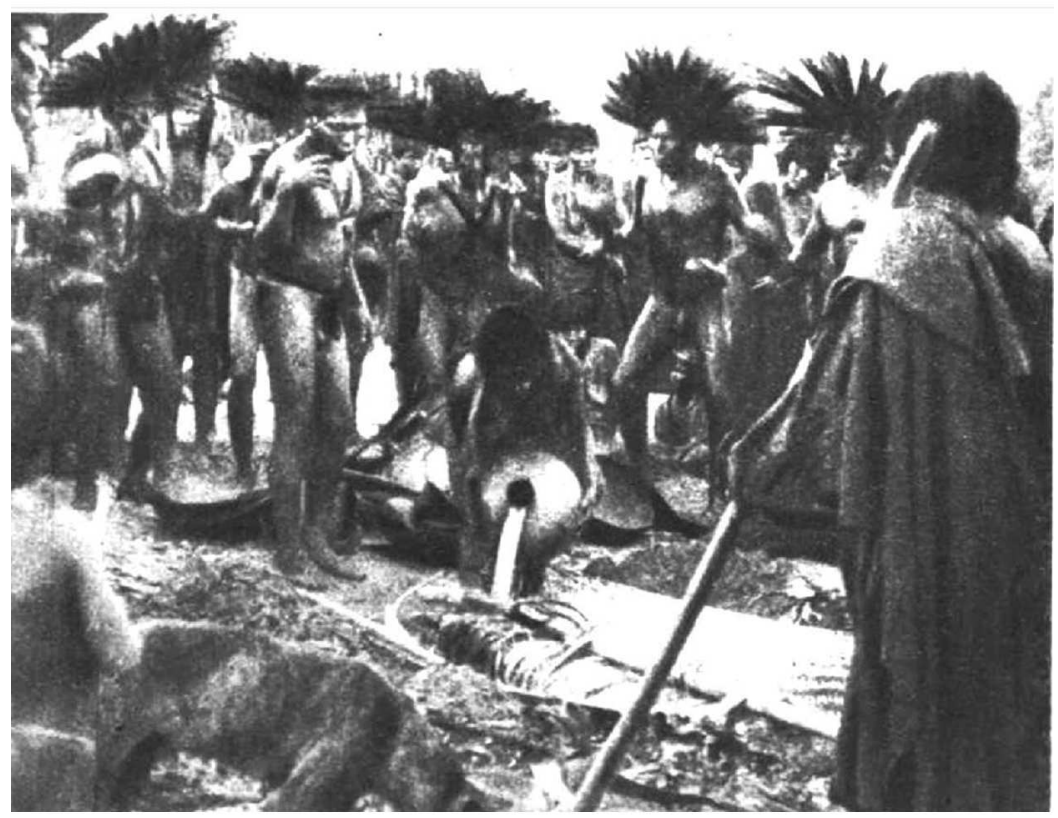

(f)

Figure 2 Continued.

dances and offering an interpretation of their meaning, but they are also important in the narrative development of the film, moderating its pacing as well as signposting its chronological progress. 
The cinematography of the film is largely observational, in the sense that mostly the camera simply follows the action. There are some exceptions: for example, when the principal male protagonists are introduced in the first ten minutes of the film, after a face-on portrait, they are clearly being instructed to turn to one side so that they may be viewed in profile, a device suggestive of 19th-century ideas about how visual media should be used for anthropometric purposes. There are also various "team photographs," particularly of the women: groups of people are lined up, clearly at the filmmaker's request, in two or more rows, sometimes with the front row sitting on the ground. But these are exceptions that prove the more general rule that there is not much evidence of the filmmaker directing events [Figure 3].

Most of the film is shot in wide-angle, particularly the ritual scenes, and to be sure, there is an abundance of jump cuts as well as some awkward examples of "crossing the line." However, these are not particularly problematic, since the sheer energy of the dancing, plus an evident sensitivity to rhythm in the editing, carries one across these potential caesuras. On the other hand there are also moments when Reis shows an awareness of the developing grammar of film language, cutting from wide-angle shots to close-ups, most notably in a short sequence where a young man is weaving a palm-fiber band, probably an armband. This starts with a wide shot of him at his loom from in front, then gives us a reverse close-up of his hands, so that we can truly admire the quality of his work, before ending on a mid-shot from the front again [Figure 4].

There are many other moments when Reis shows himself to be an accomplished cameraman with a sophisticated awareness of the aesthetic potential of the medium. The opening shot of the film, for example, shows a group of men fishing with large nets, waist-deep in the water. But instead of giving us a straightforward establishing shot, the film shows us the men through a latticework of trees and aquatic flora in the foreground. This greatly increases the interest of the shot and raises a question about what the men are doing. That is then answered in a satisfying way with a series of shots of the men now standing in canoes and beating into pulp a poisonous liana root, timbó, which they then dip in the water, drugging fish and making them easier to catch. From the angle at which these shots have been taken, it seems that Reis has actually set up his tripod in the river and filmed from there [Figure 2a]. Later, when the dancing begins, Reis often positions his camera in a particularly advantageous position, in front of the dancers but to one side, thereby allowing them to dance towards the camera and then to pass through shot, offering us an intimate look at every individual, each with his distinctive body decoration [Figure 2c].

In fact, there is so much that is familiar about Rituais e Festas Borôro that it would be only too easy to overlook just how innovative it was for the time at which it was made. Compared to the ethnographic films that immediately preceded it-such as the pioneer works of Alfred Haddon, Baldwin Spencer [Henley 2013] and Rudolf Pöch in the earliest years of the 20th century, or the "views" of exotic locations produced by the Edison or Lumière cameramen-Rituais e Festas Borôro is a much more sophisticated filmic text. Whereas those earlier works are typically just an assemblage of "one-off" takes, with rarely any linking narrative between them other than a very literal chronology, Rituais e Festas Borôro has a 


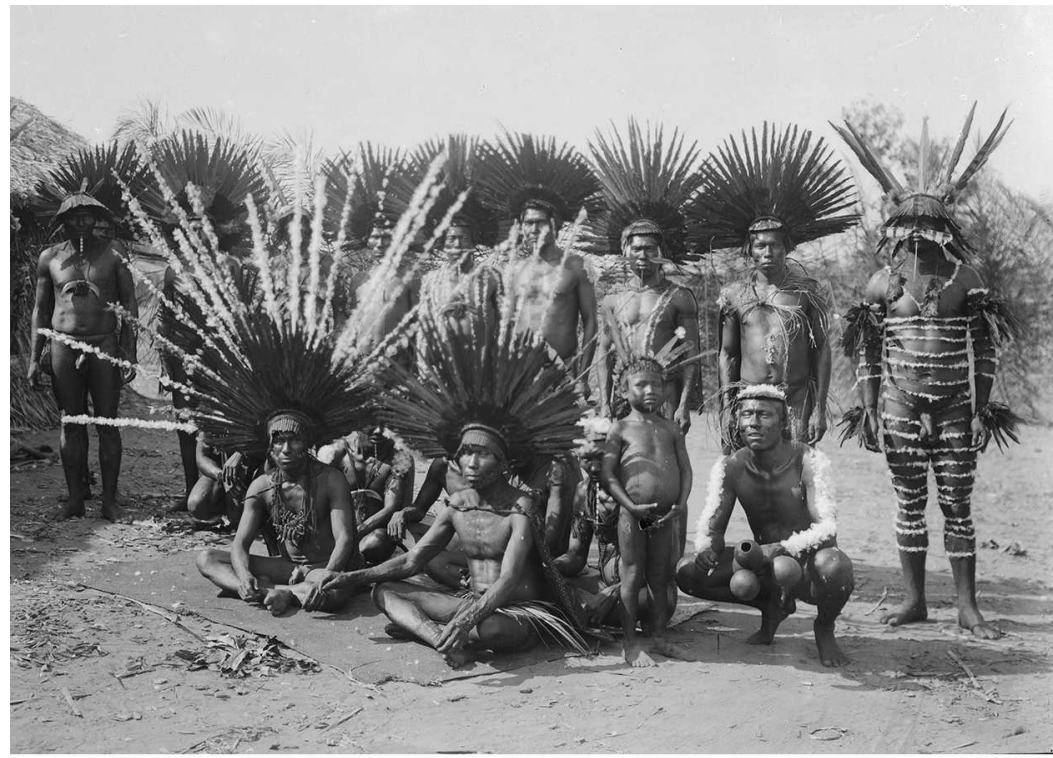

(a)

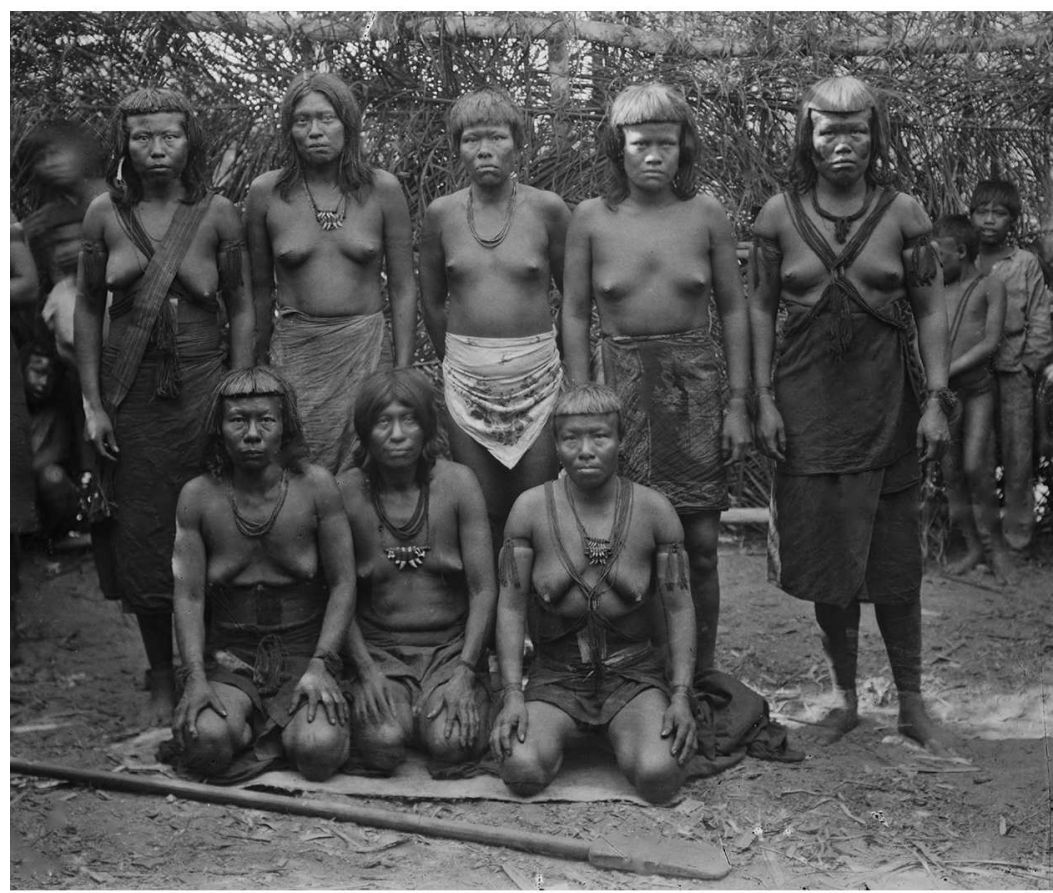

(b)

Figure 3 "Team" photographs-male and female. (Stills taken at the same time as the filming, probably by Reis's assistant, Alfredo Azevedo; (c) Acervo do Museo do Índio-FUNAI, Brazil, CRNV0499 and CRNV0414) 


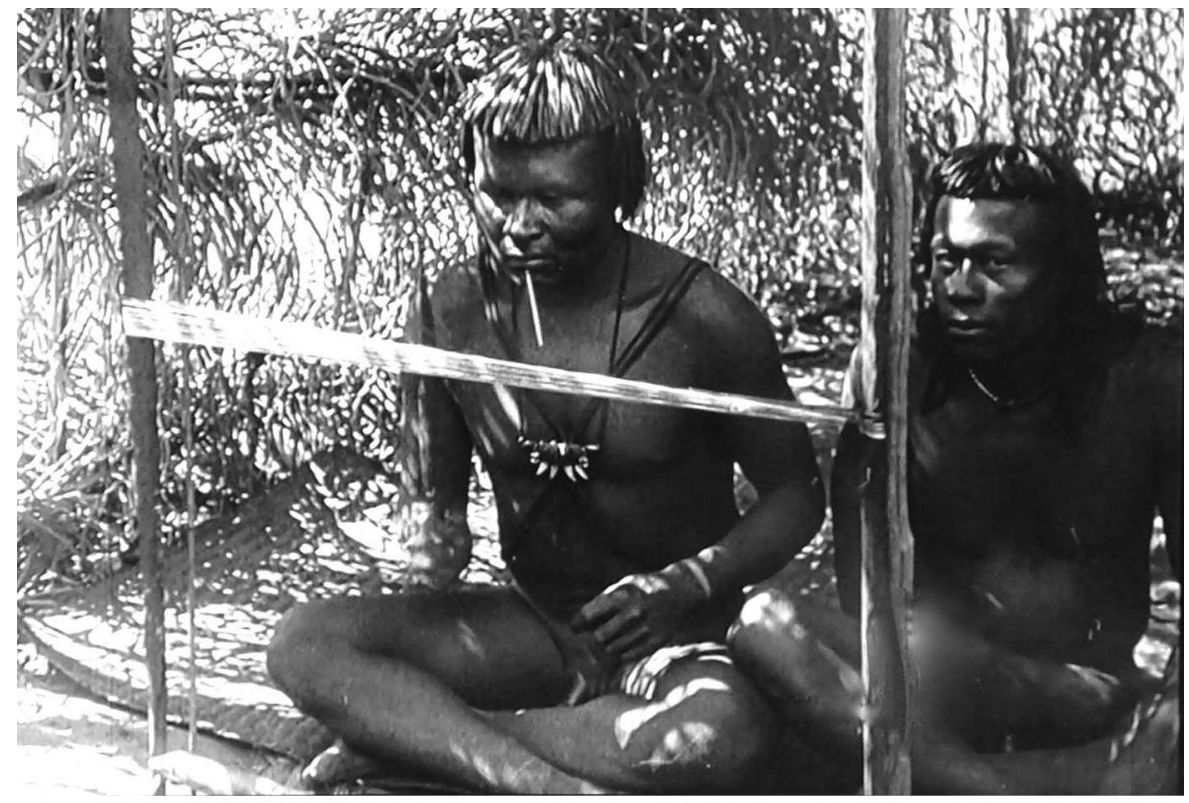

(a)

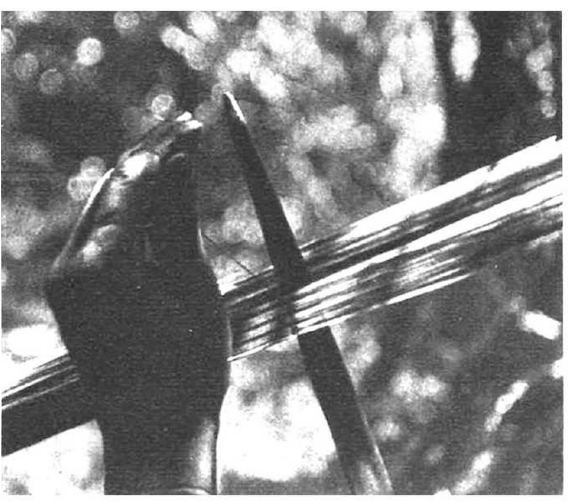

(b)

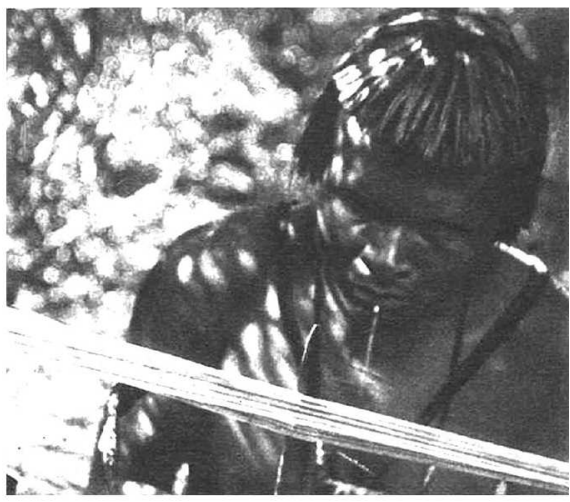

(c)

Figure 4 Reis's awareness of developing film grammar. (a) Wide-shot of young man at the loom (frame grab; (C) Acervo do Museo do Indio-FUNAI, Brazil). (b) Reverse close-up (Rondon 1946: 261; (C) Acervo do Museo do Índio-FUNAI, Brazil). (c) Return to frontal mid-shot (Rondon 1946: 261; (C) Acervo do Museo do Índio-FUNAI, Brazil).

clearly structured narrative linking all the different phases of the film through a variety of devices, some visual, others textual. Although the overarching structure of the film remains chronological, this chronology, as we discuss below, has clearly been manipulated for narrative effect.

At the same time, this film is also quite different in its general format from the expedition films and "travelogues" that were becoming an increasingly common 
genre of non-fiction filmmaking by the second decade of the 20th century [Lindstrom 2016]. These usually consisted of a series of events and situations held together narratively by the structure of the filmmakers' journey, with little or no sustained engagement with any particular event or situation encountered along the way. Prior to making Rituais e Festas Borôro, Reis had made two expedition films of this kind himself. But given that it follows a series of events in a single community over several weeks without any reference to the journey of the filmmaker, Rituais e Festas Borôro can be considered as belonging to a distinct genre of film.

It is also significantly different from the genre of ethnographic films that in the 1920s would come to be dubbed "documentary" in the English-speaking world, as exemplified particularly by the early works of Robert Flaherty, Nanook of the North [1922] and Moana [1926]. Notwithstanding that these works are seen as the $u r$-films of the documentary genre, in actual fact they involved so much dramatization and re-enactment that it is doubtful that, if made today, they would be classified as "documentary" at all. By contrast, although there was clearly some degree of directorial intervention as well as selectivity in the shooting during the making of Rituais e Festas Borôro, not to mention considerable manipulation of chronology at the editorial stage, there is nothing in this film that compares to the dramaturgical mise en scène that is central to the early Flaherty works.

In fact, it is not until the transitional Grass [Cooper and Schoedsack 1925] that one begins to find ethnographic documentaries in the modern sense that, like Rituais e Festas Borôro, are based directly on actuality footage and that also arise from an intensive engagement with one particular community or situation. Among the examples that spring to mind from the 1930s are the various short documentaries made by Marcel Griaule among the Dogon of West Africa, and Bougainville, the lengthier though less well-known film directed by the French missionary-ethnologist, Fr. Patrick O'Reilly, which offers an ethnographic overview of life on the Melanesian island of the same name [see Filmography for further details]. But even in the 1930s, works of this kind were unusual among the broad sweep of films touching on ethnographic topics. For the most part these continued to involve some element of dramaturgical re-enactment or if they involved actuality footage, this would have been gathered opportunistically in the course of an expedition.

Rituais e Festas Borôro thus stands out as a unique work in its time and moreover one that in its general format would remain unusual for the best part of two more decades. What was it then that motivated Luiz Thomaz Reis to make a film of this kind? The question becomes all the more intriguing when one considers that although he continued making films for twenty more years, he never again made one like Rituais e Festas Borôro. Instead, like most of his contemporaries, he thereafter made expedition films, remaining constantly on the move, and never again engaging in the kind of sustained relationship with his subjects as when making Rituais e Festas Borôro. In order to explore why this film is so unique, both as a pioneering ethnographic film and as an element of Luiz Thomaz Reis's personal filmography, we need to look at the historical and political contexts within which it came into being. 


\section{THE CONTEXTS OF PRODUCTION OF RITUAIS E FESTAS BORÔRO}

Luiz Thomaz Reis was head of the photography and film unit of the Rondon Commission when he made Rituais e Festas Borôro. This was an agency of the Brazilian government charged with establishing a system of telegraphic communication between the major cities of the eastern seabord and the country's western land frontier. But from the thorough report that Reis produced after the filming was completed, which he presented to Capt. Amilcar Armando Botelho de Magalhães, who headed the bureau of the Rondon Commission in Rio de Janeiro, it is clear that the decision to make Rituais e Festas Borôro did not originate with Reis himself.

For here, in the very first line of the report, Reis describes the filming project as an "instruction" (the Portuguese word is incumbência), while in a short preface to the report he remarks that in carrying out this work he had striven as much as possible "to fulfill the wishes" of Botelho de Magalhães and the "Head of the Commission" [Reis 2011: 266-267]. The latter person is not named, but there was no need to since the Commission itself was named after him: he was none other than Cândido Mariano da Silva Rondon (1865-1958), then a LieutenantColonel in the Brazilian army, and one of the most charismatic figures in early 20th-century Brazil. Given that Botelho de Magalhães was a functionary of the Commission and little more than Rondon's amanuensis, the ultimate source of the decision to make Rituais e Festas Borôro was therefore in all probability Rondon himself [Figure 5]. ${ }^{7}$

Unfortunately, in his report, Reis does not go on to identify the precise motivation lying behind the incumbência that he had been given. All he says is that he was instructed to film "the Bororo Indians living in the colony of São Lourenço" and, on the way, to screen one of his earlier films, Os Sertões de Matto-Grosso, as he passed through Cuiabá. With no explicit evidence in the report itself, we are obliged to look further afield to explain this incumbência, examining not only the general mission of the organization for which Reis was working, but also the ideas and personal interests of the head of that organization, Lieutenant-Colonel Rondon.

The Rondon Commission had its origins in a long-standing project initiated in Brazil shortly after the new Republic was established in 1889. For several decades before that, Brazil had been involved in a series of military conflicts with its western neighbors, mainly Bolivia and Paraguay, with the result that the building of telegraph lines between these frontier regions and the politically and economically important cities in the east of Brazil became of vital strategic importance [Figure 1]. In Mato Grosso this project was initially directed by an army engineer, Maj. Ernesto Gomes Carneiro who, like many Brazilian army officers of the time, was inspired by the sociopolitical doctrine of Positivism, whereby "order and progress" - the phrase emblazoned even today on the national flag-would be achieved by the entirely rational exploitation of both human and natural resources, and by deployment of new technology.

Central to the Positivist doctrine was the idea that Christianity represented merely one stage in human social evolution which would be displaced by a more rational, entirely atheistic credo, albeit one that could also be disseminated 


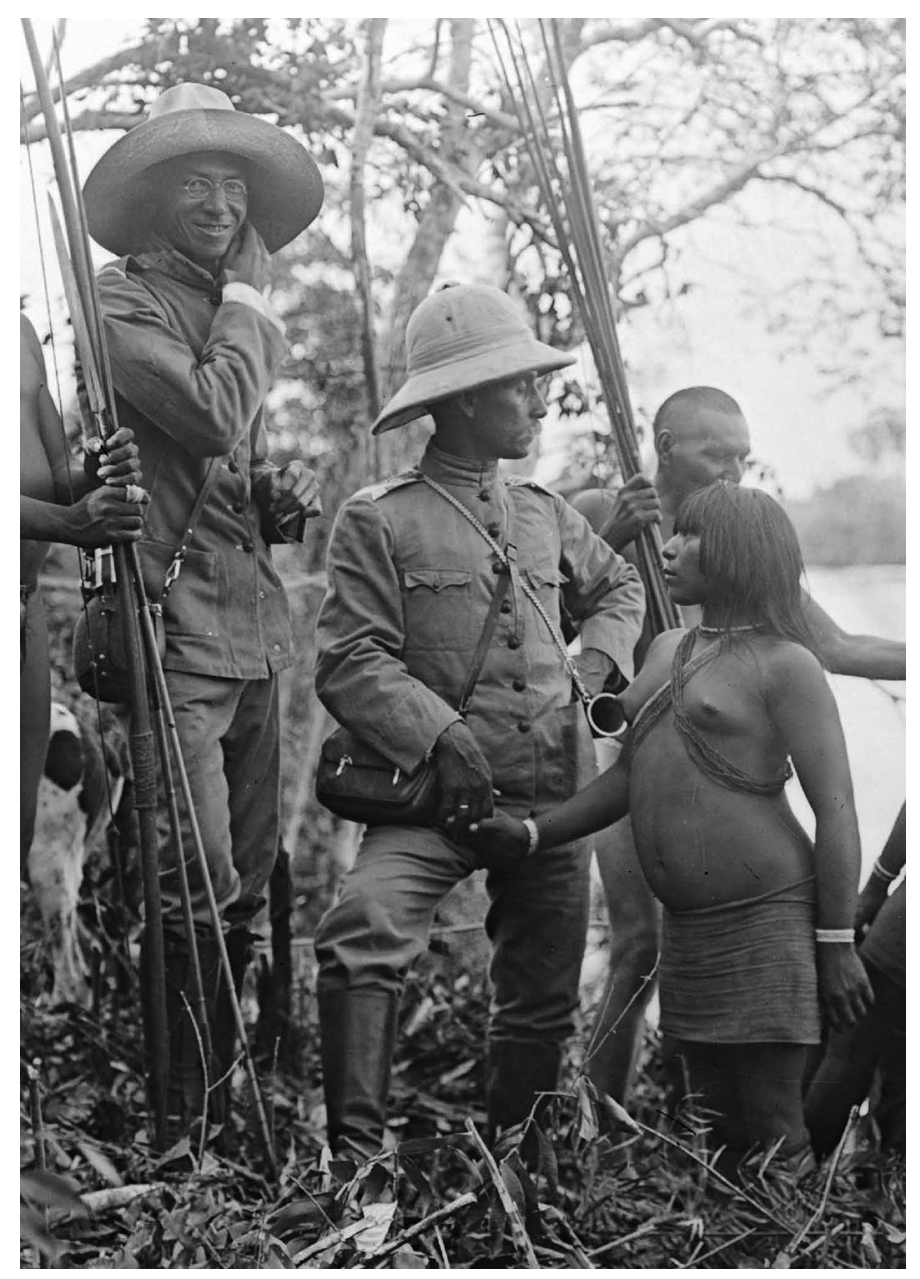

Figure 5 Reis with Rondon (center) among the Paresi in 1912-13, soon after the creation of the film unit of the Rondon Commission. (Still (C) Acervo do Museo do Índio-FUNAI, Brazil, CRNV0614)

through a Positivist "church." As far as the interior of Brazil was concerned, the proponents of Positivism argued that representatives of the Brazilian State, working in accordance with rationalist principles, should displace Christian missionaries as the principal agents for integrating indigenous populations into the national society. Although Positivists believed that this process of integration should involve education in the Western sense and incorporation into the national labor force, and it would necessarily also involve social and cultural change for the indigenous population, they maintained that this integration should be achieved by entirely peaceful means and that indigenous groups' rights over their lands and resources should be protected. In the ideological terms in which the issue was debated within Brazil at the time, the Positivists were arguing that the religiously inspired "catechization" delivered by missionaries 
should be displaced by reason-based "protection" offered by the State [Freire 2011: 20-25; Lima 2011: 207; Ribeiro 1996: 151-157]. ${ }^{8}$

Rondon became the adjutant of Gomes Carneiro in 1890, and was deeply influenced by both his personal example and his Positivist ideas. Rondon even became a member of the Positivist Church and remained so throughout his long life. When Gomes Carneiro was shifted to other duties in 1892, Rondon took a leading role in directing the project, though the Commission that would bear his name was not actually constituted formally until 1900. Under his direction, in addition to erecting $4,500 \mathrm{~km}$ of telegraph lines and 55 stations, the Commission expanded its remit beyond these infrastructural tasks to support scientific studies in cartography, astronomy, geology, botany, zoology, and even ethnographic studies [Hemming 2003: 4-14; Portugal Lasmar 2011: 36-37, 46-49; Vangelista 2008: 81-123].

With the indigenous population Rondon continued his predecessor's practice in following a strict policy of non-violence: even when such groups attacked the work crews for the telegraph lines Rondon forbade any kind of violent retaliation. He believed these attacks were merely symptoms of the violence that indigenous peoples themselves had suffered at the hands of previous invaders of their territory, particularly rubber tappers. In order to establish peaceful relationships Rondon required that people be offered gifts of steel tools, food and medicine instead. This strategy largely proved successful and the telegraph lines seem to have been built without any major loss of life on either side. Some indigenous groups, including the Bororo, even consented to work as laborers on the construction and played a vitally important role when other labor was scarce [Botelho de Magalhães 1926: 264; Ribeiro 1996: 131-137; Viveiros 1958: 130-131]. ${ }^{9}$

Aside from his exposure to Positivist ideas, another reason why Rondon was sensitive to the rights of the indigenous people would surely have been the fact that he was himself of indigenous descent. Born in 1865, he was a native of Mimoso, a small village in the interior of Mato Grosso State, lying midway between Cuiabá and São Lourenço-the Bororo community where Reis would later shoot Rituais e Festas Borôro [Figure 1]. This area fell within traditional Bororo territory and at the time of Rondon's birth it was a region of both indigenous and non-indigenous settlement. On his mother's side Rondon was of mixed Bororo and Terena descent, while on his father's side he could trace Guaná ancestry. But of all these forms of indigenous inheritance, it seems that the Bororo was the most prevalent, and there are many reports that Rondon had an effective operational command of the Bororo language [Hemming 2003: 2, 4].

Moreover he was a regular visitor to Bororo villages. According to his principal biographer he was not only addressed by the Bororo as pagmejera, literally "our chief," but was also often the subject of honorific bacororo chants during his visits. Rondon also often saw Bororo funerals, and was fully aware both of the great importance of this ceremony to the Bororo and of its remarkably elaborate nature. ${ }^{10}$ In 1900 he witnessed a funeral at Kejara, the village that Lévi-Strauss would visit three decades later, and was greatly impressed by the beauty and what he called the "priestly" nature of the singing and dancing. The following year he again attended a funeral, this time for a number of Bororo men who had died after contracting measles caught while working on the telegraph lines; while in 
1911 he attended the funeral of a leading Bororo man, one Chico Arara, and even contributed the jaguar skin, which together with the jaguar's claws and teeth forms an important part of the mori, that is, the symbolic retribution for the death of a person that is an integral feature of the Bororo funeral [Viveiros 1958: 12, 126, 317-318, 357-358].

In 1910, a decade after the setting up of the Commission, Rondon was also instrumental in the creation of the Serviço de Proteção aos Índios [SPI], and was nominated as its first director; though strictly speaking this was an autonomous agency within the Ministry of Agriculture rather than a dependency of his Commission. The creation of the SPI was a gesture of great political significance in Brazil at that time, since many people, including certain leading members of the intelligentsia, believed that indigenous groups should simply be physically exterminated if they stood in the way of economic development. ${ }^{11}$

The SPI set up a series of posts in indigenous communities across Brazil to provide those communities with protection against the invasion of their lands by non-indigenous settlers. At the same time however the SPI aimed to integrate the indigenous people into national Brazilian society by promoting both economic and cultural change. This nation-building aspect of the SPI was indicated in the full title by which it was known until 1918. This was rendered in the acronym, SPILTN, where the last three letters corresponded to Localização de Trabalhadores Nacionais, literally the "the Localizing of National Workers." It was a reference to the labor pool that government aimed to create, that would include both the landless descendants of former slaves, the last of whom had been definitively set free only in 1888, and the indigenous peoples being incorporated into the national society [Hemming 1988: 20; Portugal Lasmar 2011: 59]. One of the first indigenous communities to become the site of an SPI post was São Lourenço, the Bororo village where Reis shot his film. Here, the establishment of a small sugarcane-processing factory was an important example of the SPI mission to turn the Bororo into productive agricultural workers.

The foundation of the SPI was seen by the Catholic missions in Brazil, with good reason, as an attempt to displace them from their proselytizing work with indigenous people, and they campaigned intensively against it, though without success [Hemming 2003: 21-22]. Rondon himself retained a somewhat ambiguous attitude towards these missions: while he would sometimes acknowledge, particularly later in life, that they had a role to play in protecting indigenous groups from other much more unscrupulous invaders of indigenous groups' lands, such as the rubber tappers, he thought it far preferable, on grounds of general principle, that the process of incorporation of the indigenous people into the national society should take place without the need for them to pass through the process of being "catechized" by missionaries [Vangelista 2014: 121; Viveiros 1958: 344-347, 558-559].

Furthermore, in the particular case of the Salesians, an Italian missionary order working among the Bororo, Rondon lost no opportunity to be critical. The Salesians had set up their first mission among the Bororo in 1895 at the site of a government military colony at Teresa Cristina, not far from the Bororo village on the banks of the São Lourenço river where the film was made. But this mission only lasted until 1899, when it was closed down by the State government amid allegations of mistreatment of the indigenous people and sexual 
improprieties. Three years later the Salesians set up a new mission headquarters some $150 \mathrm{~km}$ to the northeast, at Meruri on the Barreiro river (a tributary of the Rio das Garças and the Araguaia rivers), where they remain to this day. But even here the Salesians continued to be subject to the most intense criticism by leading secular figures in Brazilian politics, including particularly Rondon. After visiting the Salesian mission at Meruri in 1911 he wrote an open letter to the Minister of Agriculture, then newly charged with the direction of the SPI, in which he excoriated the Salesians on a series of counts, including the practice of separating mothers from their children, forcing Bororo men to work for the mission at gunpoint, and inflicting the most severe physical punishments [Caiuby Novaes 1997: 65-101; Hemming 2003: 236, 731; Vangelista 2008: 68, 110].

It was within the context of this particular constellation of ideas, attitudes and policies towards the integration of indigenous peoples into national society that Luiz Thomaz Reis was recruited by Rondon to work for his Commission, first as a photographer and then later as a cinematographer. These circumstances, we will argue, are of crucial importance in understanding why Rituais e Festas Borôro came to be made.

\section{THE FORMATION OF LUIZ THOMAZ REIS AS A FILMMAKER}

Rondon had a very developed sense of the potential of visual media for the work of his Commission, not only as a complement to the scientific studies that it carried out but also as a means of publicizing the Commission's work to the political and cultural elite of Rio de Janeiro and other seaboard cities. Even as early as the 1890s he had ensured that photographers were part of his frontier field expedition teams. Some of these photographers were recruited from commercial studios, others were seconded from the army. Luiz Thomaz Reis was among the latter, becoming a member of the Commission in 1910 when he held the rank of 2nd Lieutenant [Portugal Lasmar 2011: 182-223].

Not long after joining the Commission Reis persuaded Rondon that the photographic unit should expand its remit to include moving images. Rondon therefore sent Reis to Europe to buy the necessary equipment, primarily two cameras, a Williamson bought in London and a Debrie Studio from Paris. At the same time, Reis bought 7000 meters of Lumière "Tropical" 35-mm film [ibid.: 93]. Both cameras were hand-cranked, but whereas the Williamson could take a film spool of a maximum of $100 \mathrm{ft}$. $(30 \mathrm{~m})$, the Debrie could operate with spools of up to 400 feet $(120 \mathrm{~m})$. Assuming a standard cranking speed, this corresponded to durations of slightly less than two minutes in the case of the Williamson, and in the case of the Debrie to slightly over six minutes. Perhaps for this reason, the Debrie was Reis's preferred camera, and he used it for "the most important studies" [Reis 1945: 100]. In one of his best-known films, Ao Redor do Brasil, released in 1932, the opening shot is of Reis himself operating a Debrie, presumably the same camera he had bought in Paris two decades before [Figure 6].

At the time that he made Rituais e Festas Borôro Reis was still relatively inexperienced as a filmmaker, having only made two expedition films. Although one may presume that he had been instructed from a technical point of view in how to operate the cameras by the European vendors, there is no evidence that he ever 


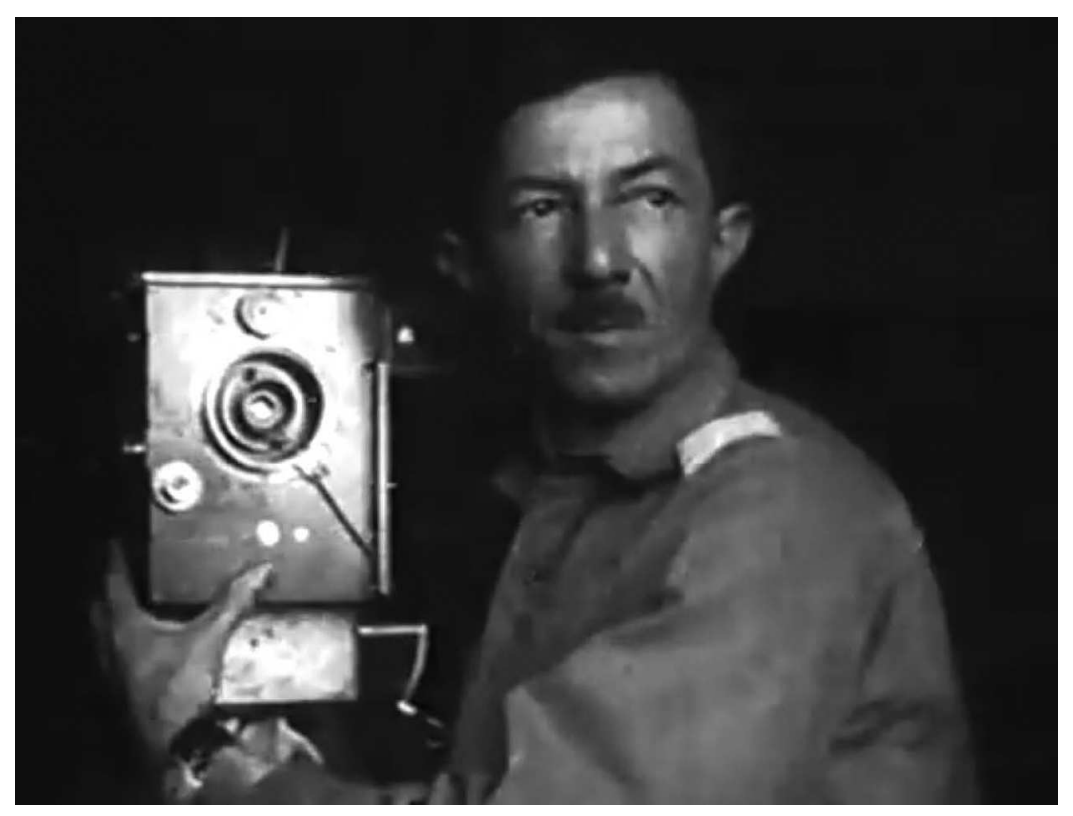

Figure 6 Luiz Thomaz Reis with the Debrie $35 \mathrm{~mm}$ camera in the opening sequence of Ao Redor do Brasil (1932).

received any guidance in more editorial matters. Nor does he appear to have consorted with other Brazilian filmmakers of the day, either in Rio de Janeiro or in the provinces. For example, in the course of his career, he must have passed through Manaus many times, but no record has so far come to light that he ever met with Silvino Santos, the other most celebrated expeditionary filmmaker of that era in Brazil, who was based in this city. Rather, Reis seems to have been entirely an autodidact, technically resourceful as well as talented. Not only did he shoot most of his material in the physically demanding conditions of the Brazilian interior but he developed it there too. In order to facilitate this process, he devised his own customized portable laboratory, which allowed him to develop his negatives without mosquitos or other insects getting into the chemical baths.

Of the two films that Reis made prior to Rituais e Festas Borôro, the first was Os Sertões de Matto-Grosso, shot in 1912-13, which, as the title suggests, follows an expedition across the savannas of Mato Grosso. Although that film is now lost, it is clear from a list of the intertitles and a few surviving fragments that it consisted of a series of vignettes. Some were geographical, showing features of the natural landscape, others offered largely posed portraits of indigenous people whom the expedition encountered en route, while others again recorded the logistical difficulties of the expedition [Portugal Lasmar 2011: 260-263]. The other expedition film that Reis made prior to Rituais e Festas Borôro concerned a hunting and animal-collecting expedition to Central Brazil that Theodore Roosevelt made in the company of Rondon around the turn of the year 1913-1914. This film is also lost and seems to have been something of a failure: there were many problems during production, and Reis asked to leave the expedition early since he did 
not have sufficient resources to carry out his role. The film appears never to have been fully edited, and was only screened in public a few times [ibid.: 52].

Os Sertões, on the other hand, was highly successful, and was shown to enthusiastic audiences across Brazil. On its commercial release in October 1915 it was screened to some 20,000 people over five days in Rio de Janeiro and subsequently to many more audiences in São Paulo and elsewhere. It has been estimated that over the six-month period running up to March 1916 more than 65,000 people came to screenings of one or the other of the two films. The takings were used to contribute to various charitable causes, to the SPI and even to the central bureau of the Rondon Commission [Lobato 2015: 303-305; Portugal Lasmar 2011: 148; Rodrigues 1982: 2]. Later, as detailed in his report, on his way to shoot Rituais e Festas Borôro in São Lourenço, Reis took a copy of Os Sertões with him and arranged screenings to paying audiences at local cinemas in various towns and cities along the way.

\section{THE MAKING OF RITUAIS E FESTAS BORÔRO}

It is clear from Reis's report that the shooting of this film was by no means a casual enterprise. Departing from Rio de Janeiro in May 1916, by now promoted to Captain and accompanied by an assistant, the photographer Alfredo Azevedo, Reis first went by train to Corumbá, on the banks of the Paraguay river, some $1800 \mathrm{~km}$ to the west and situated on the frontier with Bolivia [Figure 1, inset]. He took along a lot of baggage, including forty boxes of gifts for the Bororo. In Corumbá he screened Os Sertões in the local cinema and shot some $500 \mathrm{~m}$ of film (roughly 25 minutes) on various local topics, before proceeding north by river steamer to Cuiabá. He also intended to film there, though he seems not to have actually done so until on his way back, when he filmed a military encampment on the outskirts of the town. After developing the footage that he had shot in Corumbá Reis then set out for São Lourenço with a mule-train of fourteen animals, nine of which were carrying the forty boxes of gifts for the Bororo. Eventually, on 30 July, after seven overnight stops and more than two months after leaving Rio de Janeiro, the expedition reached the village, where Reis and Azevedo would remain until October.

Given the substantial deployment of resources it is inconceivable that this expedition could have taken place without the explicit endorsement of Rondon as Head of the Commission. Certainly, the decision to go specifically to São Lourenço would have been entirely congruent not only with the particular importance of the Bororo in the building of the telegraph line but also with Rondon's personal attachment both to this indigenous group and to this part of Mato Grosso. It would also have been congruent with the fact the SPI post at São Lourenço, being among the first ones set up in the whole of Brazil, represented something of a showpiece for the advantages of "protection" as a mode of integrating indigenous people into national life, as contrasted with the "catechization" offered by the Salesians.

There are also grounds for supposing that Reis went to São Lourenço for the specific purpose of filming a funeral. At first sight, this might seem rather unlikely, 
since it involves the assumption that Reis would have committed himself to two months traveling to São Lourenço, with all the baggage, without the certain knowledge that a funeral would indeed occur when he got there. However, the sad truth is that-then as now, but particularly then due to the prevalence of the imported diseases affecting the Bororo-it was only too likely that anyone who was prepared to spend around ten weeks in a Bororo village, as Reis and Azevedo would do, would see at least one funeral. ${ }^{12}$ As already mentioned, Rondon, as a regular visitor to Bororo villages and indeed as part-Bororo himself, had certainly had a strong sense of the importance of the funeral to them as well as of its spectacular character. He would undoubtedly have known about the frequency with which funerals occurred. For this combination of reasons, it seems to us very likely that the "instruction" that Reis would have received from Rondon would have been to go to São Lourenço precisely in order to film a Bororo funeral.

However, as a filmmaker who up till then had made nothing other than expedition films, it also makes sense that Reis would also film sequences on the way to São Lourenço that had nothing to do with the Bororo. Moreover, he continued to film such sequences even after his work in São Lourenço was over. We learn from his report that on reaching Corumbá on the return journey he sent Azevedo back to Rio de Janeiro with all the film stock that had been exposed up till then and continued south on his own to film the Iguazu Falls. He also attempted, with limited success, to film a jaguar hunt, which he had not been allowed to do during the Roosevelt expedition. But all this supplementary material was kept apart from the Bororo material and integrated later into one or other of Reis's expedition films or into a film that he edited and screened locally around Mato Grosso.

Another indication that Reis did not travel to São Lourenço exclusively to film a funeral is that, of the total footage of around one hour that he shot there, about 10 per cent was scenes of the Bororo working in and around the small sugarcane factory that had been set up by the SPI [Reis 2011: 282; Figure 7 here]. None of this footage appears in Rituais e Festas Borôro, but stills taken from the footage did appear many years later, some time after Reis's death, in the first volume of Indios do Brasil, a sort of photographic encyclopaedia published by the SPI in 1946 under the general editorship of Rondon [1946: 239-247]. ${ }^{13}$

The absence from Rituais e Festas Borôro of this material about the sugarcane factory highlights an important general point, namely, that the film contains very little indication of the many contacts between the Bororo of São Lourenço and national society that were already taking place. Although it is scarcely credible, there is every reason to think that at least some of the people shown in Figure 7 also feature in the images in Figure 3a, and certainly would have appeared in the film itself. But in his report Reis makes it very clear that he wanted to show the Bororo wearing their traditional indigenous dress whenever possible.

For Bororo men on ceremonial occasions this dress consisted of the magnificent headdresses and body decorations, but below the waist, of very little other than the so-called $b a$. This is a simple penis sheath made of a rolled-up palm leaf; though the penis might then be tucked up under a thread around the waist [Figure 8a]; on festive occasions a small leaf pennant might be attached and decorated with the wearer's clan insignia. This penis sheath was still used by 


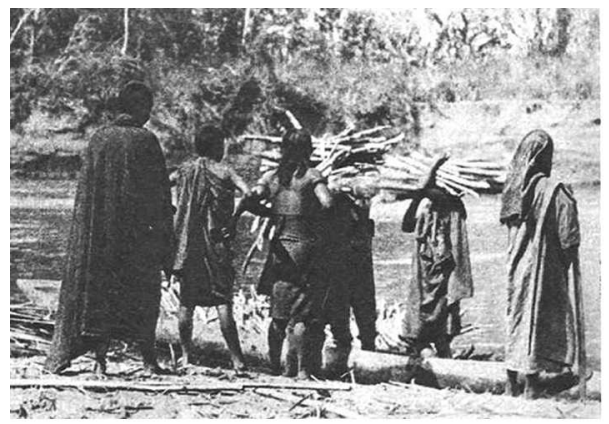

(a)

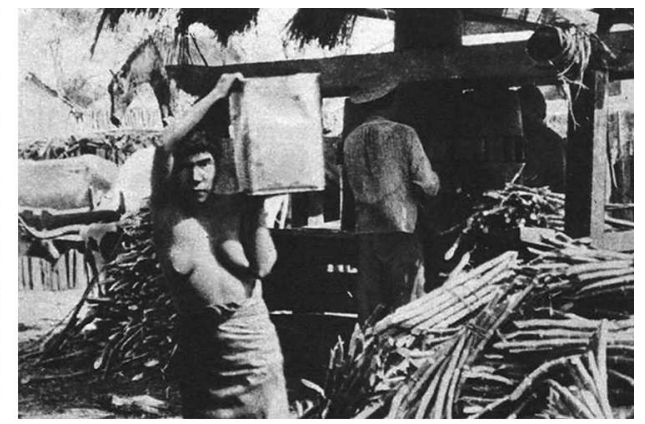

(b)

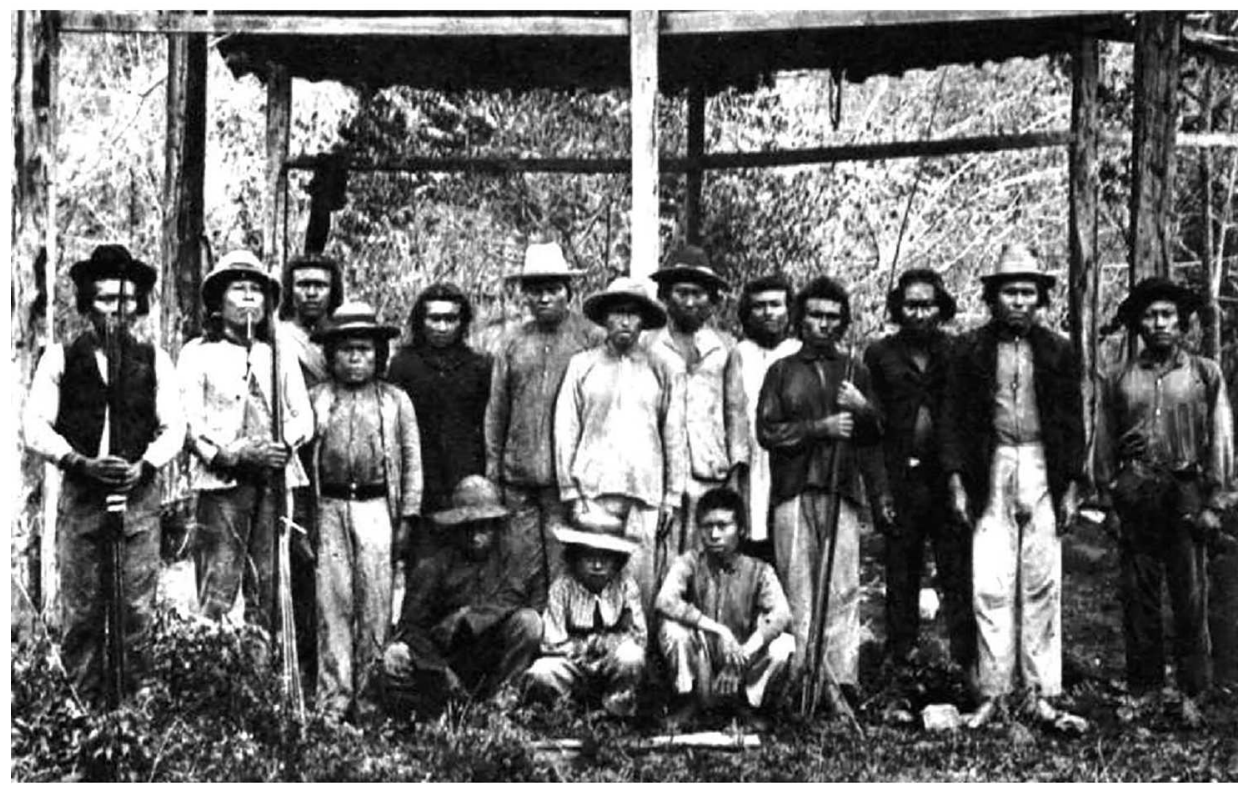

(c)

Figure 7 Stills from unused rushes shot in São Lourenço. $(a, b)$ Women working for the sugarcane factory (Rondon 1946: 244, 247; (C) Acervo do Museo do Índio-FUNAI, Brazil). (c) Men in everyday work clothes (Rondon 1946: 239; () Acervo do Museo do Índio-FUNAI, Brazil).

Bororo men until late in the 20th century. ${ }^{14}$ For women, on the other hand, traditional dress had largely fallen out of use by the time that Reis arrived in São Lourenço in 1916. As is evident from the illustrations in von den Steinen's account of his second journey through Central Brazil in 1887-88, female dress had traditionally consisted in the main of a stiff bark girdle around the waist, about $10-20 \mathrm{~cm}$ wide, with a much thinner strip of more flexible bark cloth that tucked into the girdle both at the front and at the back. It passed between the legs, but in such a way as to leave most of the pubic area and buttocks exposed [Figure 8b].

This desire to film the Bororo in their traditional dress immediately brought Reis into conflict with the manager of the SPI post at São Lourenço, a certain Sr. Barbosa. He complained to Reis that it would be highly "immoral" to film 


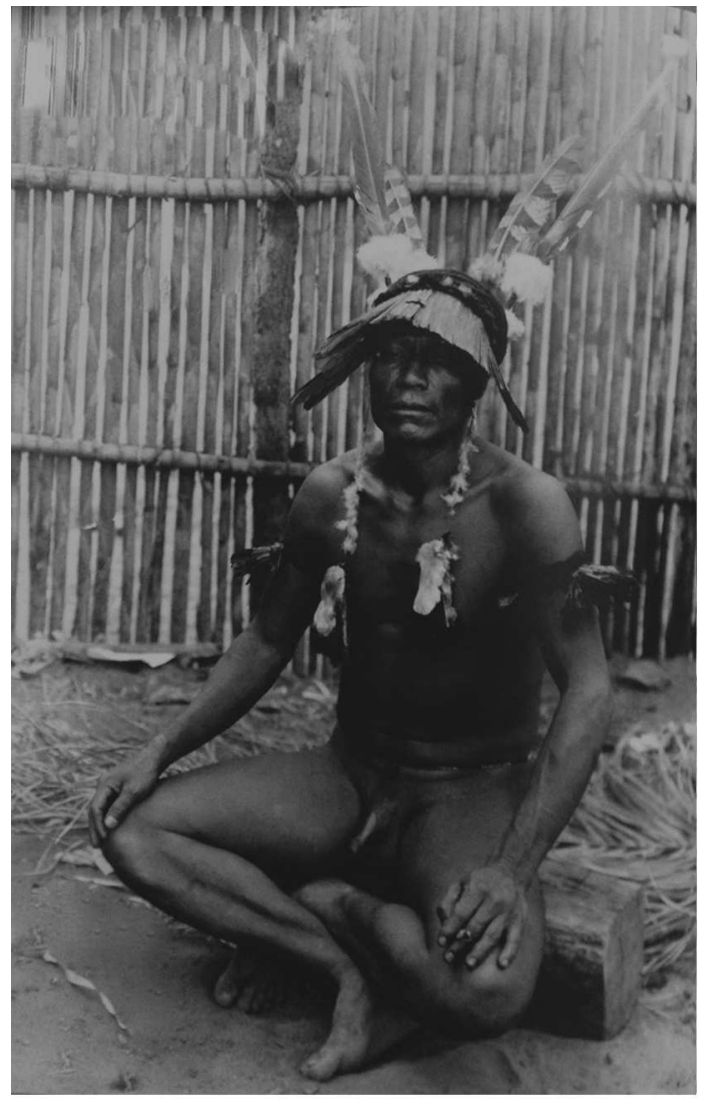

(a)

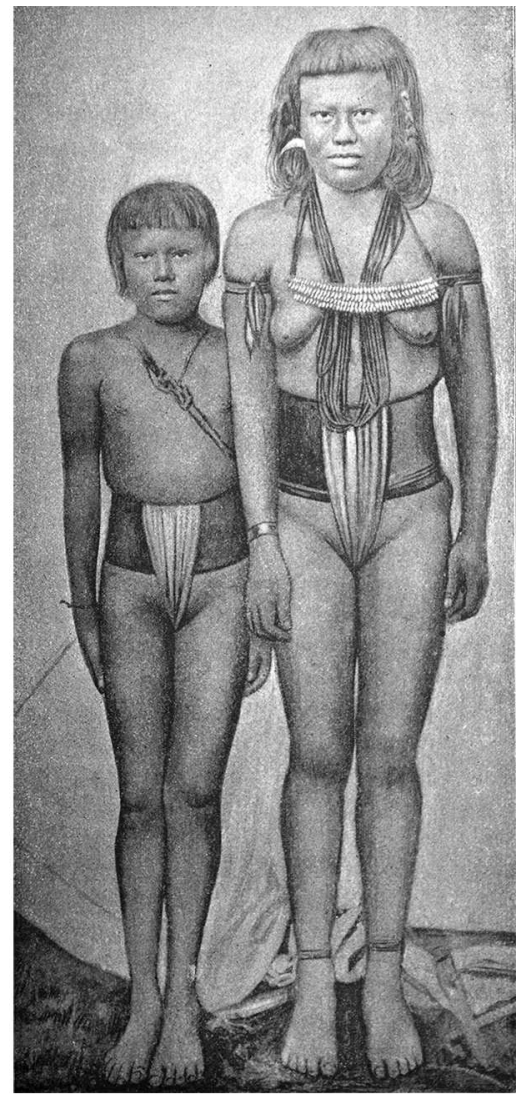

(b)

Figure 8 Traditional Bororo dress. (a) For men, as in this image of Buturaguire, aroetoráre, "evoker of the spirits," photographed by Reis himself (or perhaps by his assistant Alfredo Azevedo) in 1916 (Rondon 1946: 285; (C) Acervo do Museo do Indio_FUNAI, Brazil). (b) For women, as in this portait of a woman and her daughter in Karl von den Steinen's account of his second expedition to Central Brazil in 1887-88 [von den Steinen 1894: 473).

the Bororo in their traditional dress, particularly in the case of the women, and prejudicial to the interests of the SPI. He even claimed that Rondon himself would not have permitted it and threatened to resign if Reis went ahead with his plan. In his report, Reis is scathing about Barbosa's objections, commenting that as he was not asking the women to dress in anything other than the traditional way it would not be any great inconvenience to them, and that he had not made the long journey to Mato Grosso to film the Bororo as if they had just got back from a fashionable clothing store in Rio de Janeiro. Given that he planned to reward them with gifts, almost all the women, he claimed, were very happy to be filmed in their traditional girdles [Reis 2011: 270-271].

In the end, it seems that some sort of compromise must have been reached. While most of the men who appear in the film are wearing traditional ceremonial dress, it is clear that Reis has framed certain shots in order to avoid showing male 
genitalia; as in the shot of Buturaguire, which was clearly taken at precisely the same time as the photograph in Figure 8a, but in which the subject is cut off at the waist. There are also no women wearing bark cloth girdles in the film, certainly not visibly. Instead the women almost without exception wear simple wraparound skirts, though they do expose their upper bodies, cupping their breasts in their hands in a delicate manner when they dance. ${ }^{15}$

Other participants are fully clothed in a European manner. One woman, who appears close to the head of the line in the final dance in the film, is wearing a highly incongruous light-colored, tailored dress. At various points non-Indians wearing European dress appear briefly in shot too, including a man with a photographic plate camera on a tripod, whom we presume to be Azevedo, and a woman whose headscarf suggests that she is a nun, though perhaps simply a medical nurse.

Reis does not explain in his report exactly why he wished to film the people in traditional dress. He hints that it may have been a purely aesthetic matter, or possibly due to some sense of the need to produce a document of authentic Bororo custom for academic purposes; but it may simply have been because, having a clear sense of the need to entertain his audiences, he felt that the Bororo would excite their interest much more if people were wearing their magnificent traditional dress than if they were shown in the pathetic rags they wore in the stills from his footage about the sugarcane factory.

Whatever his precise motivation was, Reis's ambition to show the Bororo in traditional dress, proudly performing their most important religious ceremony, would have constituted a direct challenge to the Salesian missionaries, for whom the funeral was literally a diabolical cult of horror when their main goal at the time was to eradicate all manifestations of indigenous Bororo religion, as well as any aspects of their traditional culture that conflicted with European notions of propriety, such as the exposure of the body (particularly genitalia). ${ }^{16}$ Indeed we would argue that it was precisely because it represented a challenge to the missionary project of "catechization" that the Rondon Commission decided to dedicate an entire free-standing film to the celebration of the Bororo funeral rather than reduce it to just one episode in an expedition film of the kind that Reis was more accustomed to making.

At the same time this decision to present the Bororo as if they were uncorrupted by contact with modernity also played into an established literary trope that can be traced back to at least the 19th century in Brazilian literature. As exemplified particularly by the highly popular novels of José de Alencar, but also prominent in Brazilian fine-art painting of the period, indigenous peoples were acknowledged in this trope as the legitimate original inhabitants of Brazil, whose way of life was both morally and aesthetically admirable. As such, it was a way of life that should be appreciated as an element in the national identity but, very importantly, only as a contribution that belonged definitively to the past and as one that needed to be superseded [Cunha 2000, 2001]. This trope was implicit in the policies of the Brazilian State, particularly in the early Republican period, and it was one that informed the policies of both the Rondon Commission and the SPI. It is also implicit in Rituais e Festas Borôro, in the sense that the film aims to present the Bororo celebrating their most elaborate collective cultural act as if they were still living in the past with little or no outside contact. It is perhaps most poetically 
encapsulated in the final intertitle that follows the burial scene, with which the film concludes: "We have here," the intertitle declares, "a sense of the remote times of the Discovery."

\section{ON THE ETHNOGRAPHIC STATUS OF RITUAIS E FESTAS BORÔRO}

Although there appears to have been some compromise where traditional ceremonial dress was concerned, there is no doubt that the film offers a remarkably rich visual account of the Bororo funeral early in the 20th century. Among the authors of this article, both Caiuby Novaes, who first carried out fieldwork amongst the Bororo in the 1970s, and also Cunha, who did not begin until the early 2000s, can attest to the remarkable degree of continuity between the Bororo funeral as represented in Reis's film and in their own first-hand experience of this ceremony many decades later.

Even so, if one puts aside Reis's particular intentions and the many mitigating circumstances relating to the conditions under which the film was made, and considers it now strictly as an ethnographic document, one cannot avoid the conclusion that the film is flawed in a number of important respects. In many instances, Reis did not fully appreciate what he was filming: ironic though it might seem, with the benefit of the many ethnographic studies that have been done since his time, we are now in a better position to understand what Reis filmed than he was himself. There are also certain important moments in the ceremony that are simply missing from the account in Rituais e Festas Borôro. But if these could all be considered errors of omission there are also certain important errors of commission, that is, distortions that Reis introduced quite knowingly into his filmic account, for reasons that we shall consider below. However, in order to assess the ethnographic status of his film we must first begin by sketching out, in a summary manner, a contemporary understanding of the Bororo funeral so that we can measure Reis's account against it. ${ }^{17}$

As with all aspects of their social life, the Bororo funeral ceremony is underpinned by their famously elaborate system of moieties. These are laid out on the ground for all to see in the ideal-typical village, which is conventionally circular and oriented around a central east-west axis following the daily trajectory of the sun [Figure 9]. Each moiety is ideally then subdivided into four clans, each with one or more houses aligned along the perimeter of the village. These clans are considered the holders of certain important properties, mostly immaterial, and made up of such things as songs, names, patterns of body decoration and dances, including those that are performed during the funeral ceremony. The moieties are exogamous and matrilocal, in that men are required to marry a woman from the other moiety and upon marriage to leave their natal houses to go to live in their wife's clan's house on the opposite perimeter of the village. However there is a delayed reciprocal exchange principle implicit in this marriage rule, in that it ensures that in the following generation the sons of those who have married out will marry back into the moiety from which they themselves came and often, in practice, back into the very same clan house.

In the central plaza of the village there is typically another large house, which appears in the background of many of the shots of dancing in the film. Reis 


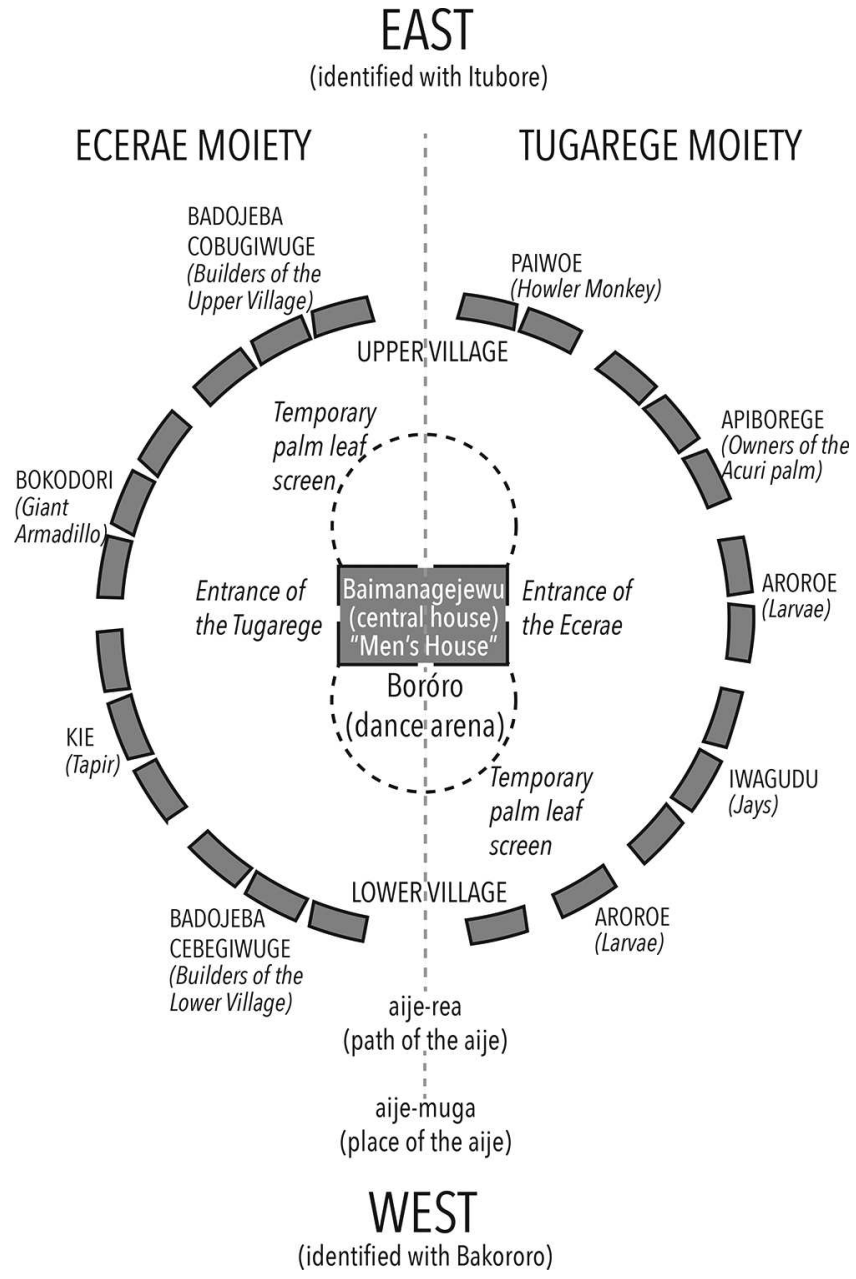

Figure 9 Idealized Bororo village lay-out [after Albisetti and Venturelli 1962: 436].

describes this structure in the intertitles as a "temple,' though that is not really appropriate since, while certain important religious activities do take place there, including during the funeral ceremony, it is the site of secular activities most of the time. In the English-language ethnographic literature it is often referred to as the "men's house" since on a day-to-day basis it is frequented exclusively by men, and young adult men sleep there prior to marriage. However, though serviceable, this term is not entirely accurate either, for women also enter the house by right at certain times, notably during the culminating moments of the funeral. Just to the west of the men's house, straddling the semicircles of the two moieties, there is a smaller semicircular area, known as the bororo-the term from which comes the name used by outsiders, erroneously derived, for this indigenous group. This is the area within which most ceremonial dancing and also burials take place, and it is thus here that most of the sequences in the film were shot. ${ }^{18}$ 
During the celebration of the funeral there are many examples of intermoiety exchange that complement the matrimonial exchanges just described. When people die they are thought to join the realm of the aroe, a multivalent concept in Bororo thought, but which in this context could be simply described as "ancestral spirits." The funeral ceremony is intended to effect this transition and, remarkably, the immediately deceased person is thought to take part in it. They do so through the agency of a living person who plays the role of the aroe-maiwu, a title that literally means "new ancestral spirit." This person, always a man regardless of the gender of the deceased, is appointed by the senior members of the deceased's clan and must belong to the opposite moiety. He is expected to play a leading part in the dancing and is decorated in a manner that is highly distinctive, honoring the deceased person but at the same time hiding his own personal identity. First, he is painted from head to toe with annatto and covered with a thin layer of duck down. He then puts on the pariko, the elaborate diademlike headdress of macaw and parrot feathers which, for this purpose, is fitted with a visor of yellow feathers to hide his face (as in Figure 8). Finally, to hide his body he dons a palm-leaf skirt or sometimes a cloak hanging from his shoulders to the ground. ${ }^{19}$ Meanwhile, another man of the moiety opposite to that of the deceased, along with his wife, are asked by the bereaved relatives to act as the ritual parents of the aroe-maiwu. This couple take a leading part in the practical organization of the funeral, including the disposal of the deceased's possessions, which apart from certain items of ritual paraphernalia should be taken by the aroe-maiwu and burnt, in public, on the bororo, at a particular point in the ceremony [Caiuby Novaes 2006b: 28].

This ritual relationship between the clan of the deceased and members of the opposite moiety is further reinforced by the exchange of certain material objects, one of the most important being the powari-aroe, which is a wind instrument fashioned from a small gourd into which a thin reed has been inserted. (When one blows through the mouth of the gourd, the reed vibrates to produce a sound.) This reed is cut in such a way that each gourd produces its own distinctive sound, thus testifying to the unique individuality of the person who has died. Before the ceremony a powari-aroe is decorated with feathers by the ritual father of the aroemaiwu in a pattern that accords with the clan insignia of the deceased. He then gives the newly decorated powari-aroe to the aroe-maiwu and teaches him how to play it. During the ceremony, the aroe-maiwu wears the gourd dangling from a string around his neck or over his shoulder, but afterwards he passes it back to his ritual mother to look after. Thereafter, every time there is a funeral, the powari-aroe is brought out and played. In this way, by means of these small gourds, all the past dead are remembered with every subsequent enactment of a funeral. Another important material object of intermoiety exchange during the funeral is a jaguar hide: one of the principal responsibilities of the aroe-maiwu is to hunt a large jaguar whose hide is then given to the bereaved relatives in "vengeance" for the death. This brings the funeral process formally to an end [Caiuby Novaes 2016: 99-105]. ${ }^{20}$

The spirit of the immediately deceased person is not however the only aroe that is deemed to be present at a Bororo funeral. In fact, it is believed the spirits of all dead Bororo may be present at a funeral and their presence can be made manifest 
in a variety of different ways. One way is in the form of the powari-aroe, just described; another is in the form of the dancers themselves, whose ancestral spirit identity is signaled by several means: by the pattern of their body decorations, by the dance that they are dancing, by the musical instrument they are playing or by the songs that they sing. These evocations of ancestral spirits are known as aroe-etawujedu and it is believed that when living Bororo evoke ancestral spirits in this way they are not merely representing the ancestral spirits but are actually becoming those ancestral spirits. But here too the effect of the moiety organization makes itself felt: for while each of these aroe-etawujedu is owned by a particular clan, the members of that clan do not perform it themselves; instead they invite members of a clan from the opposite moiety to do so. ${ }^{21}$

From his report, it is clear that Reis had only the most incomplete understanding of these metaphysical ideas underlying the Bororo funeral. He appears, for example, to have been entirely unaware of the fundamental idea that for them a funeral is an event that is attended by the dead as well as by the living. His film however contains many visual references to this belief. In the fishing scene with which it begins, one can see that some of the fishermen are wearing powari-aroe around their necks, clearly identifying this as a fishing expedition which forms part of the funeral ceremony and also alluding to the presence of the ancestral spirits [Figure 10]. Similarly, although Reis shows a broad range of dances and bodily decorations, and films them in an accomplished way, he clearly has no sense that these are aroe-etawujedu explicitly referring to the presence of particular ancestral spirits. Thus, for example, at various points in the dancing he shows us two contrasting wind instruments being played: one of these is a long transverse flute known as the $i k a$, the other is the panna, a sort of three-chambered trumpet made of three gourds stuck together with resin. What Reis does not appear to appreciate is that the players of these instruments are embodying the spirits of Bakororo and Itubore, the two principal mythical heroes of the Bororo, identified with the western and eastern entrances to the village respectively [Figure 9]. While Bakororo, who commands the western moiety of the village of the dead, is invoked by the player of the $i k a$, Itubore, who commands the eastern moiety of the village of the dead, is invoked by the player of the panna. More generally, instead of identifying the dances that he presents as aroe-etawujedu, Reis hazards some rather simplistic suggestions as to their meaning: one dance is said to refer to "the curassow, a sacred bird," another as intended to "drive away evil spirits," whilst a third is said to represent "warfare and victory" and a fourth is described simply as "a prodigious example of gymnastics."

On the other hand it is clear from his report that Reis did have some awareness of the importance of intermoiety exchange as a guiding principle of the funeral, as he comments at one point that "in conformity with Bororo law" the "chief" in charge of the funeral belonged to "a different division" than that of the deceased woman [Reis 2011: 278]. However, his knowledge appears to have been only partial, and in the film itself there is no direct allusion to it. Although we do briefly see several dancers who appear to be dressed in the manner typical of the aroe-maiwu there is no reference to the role of this personage in the funeral, nor to the ritual parents of the aroe-maiwu. We do not see the burning of the deceased's possessions, which is an important responsibility of the aroe-maiwu, 

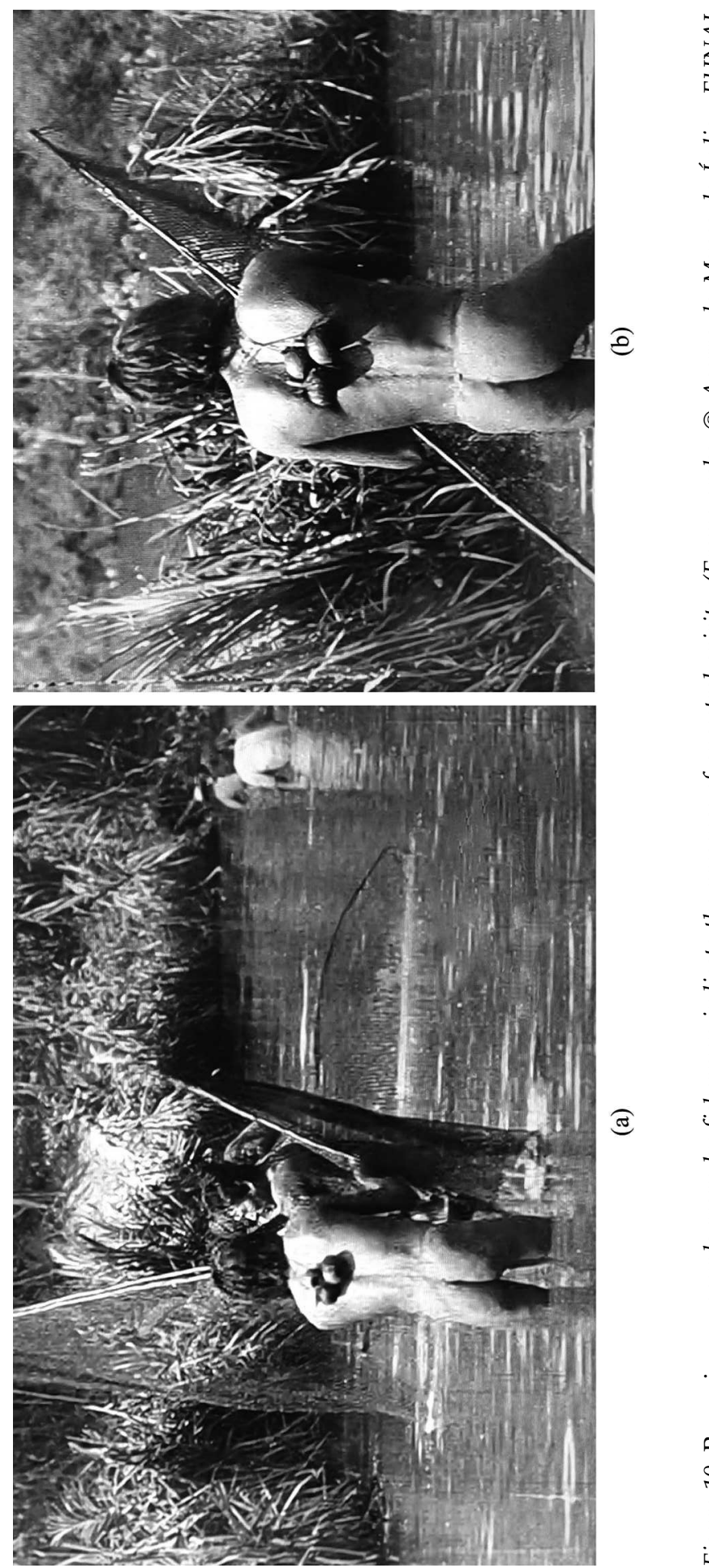

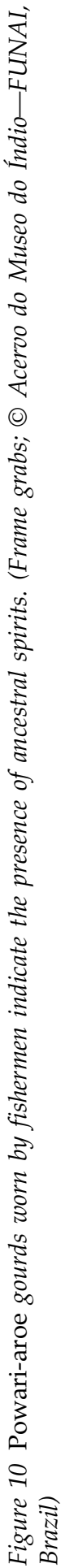


nor is there any reference to the jaguar hunt in which the aroe-maiwu is expected to engage.22

Reis was much more aware of the exclusion of women from certain phases of the funeral ceremony, and in this case there are a number of explicit references in the intertitles. Immediately following the opening fishing sequence there is a scene of a group of men and boys building a palm-leaf screen, and this is accompanied by an intertitle that explains that the purpose of this screen is "to hide the first phase of the dancing from the eyes of the women, who at this stage remain concealed in the houses." Later, about a quarter of the way into the dancing itself, another intertitle explains that women are now allowed to participate in the dancing, and shortly afterwards they are indeed shown doing so, while in the background we can see that the palm-leaf screen has been taken down. Later still, towards the end of the film, when the men retire to perform the aije ceremony, an intertitle explains that this "takes place in the closest part of the bush where women cannot catch the slightest glimpse of what happens."

However, this account of the exclusion of women is far from complete. The reason that the Bororo themselves give for the exclusion of women from the first part of the funeral ceremony is that they are "too weak" to withstand the sight of the aroe, the ancestral spirits, as these become literally embodied in the men of the village. Of all the aroe the one that is deemed most dangerous for women is known as aije, a term that is used not only of the particular ceremony that takes place during the funeral, as Reis indeed shows us, but also of an important figure in Bororo origin mythology who is strongly associated with male sexuality. Aije is also the term used to refer to a sound-making device usually referred to as a "bull-roarer" in English-language texts. Among the Bororo this consists of a thin, flat and oval flange of planed wood, between 30 and $90 \mathrm{~cm}$ long, which is decorated with clan insignia. This too is strongly associated with masculinity by the Bororo, for they explicitly compare it to a giant phallus. It is attached by means of a string to a long, flexible rod of about three meters and swung around in the air, producing a throbbing sound that varies in pitch according to its length. This is said to be the cry of the aije ancestral spirit, considered to be terrifying to women [Figure 11a]. ${ }^{23}$

Around the middle of the film there is a shot of a man being showered with water from an earthen pot in the foreground, while in the background another man is whirling a large bull-roarer around in the air, though this is difficult to see given the primitive quality of Reis's film stock, and when the image is paused it is reduced to a blur. The body of the man doing the whirling is painted black but is covered with spots of white down, which identify him as Bokwojeba, an ancestral spirit. To his right in the shot another man is leaning on a large bullroarer on which the clan insignia are visible. Even further in the background there is a house with its main door blocked up by a mat, presumably so that the women and children inside should not see the bull-roarer as it is being operated [Figure 11b].

But none of this is remarked upon by Reis. Nor does he offer anything approaching a complete or accurate account of the aije ceremony itself, which is shown in a sequence towards the end of the film. Recent ethnographic research has established that this ceremony constitutes the supreme apotheosis of 


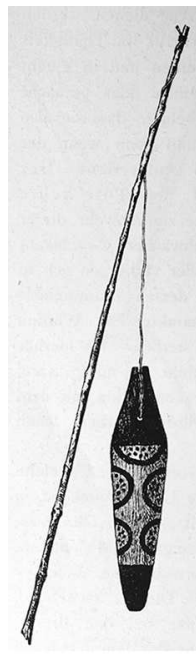

(a)

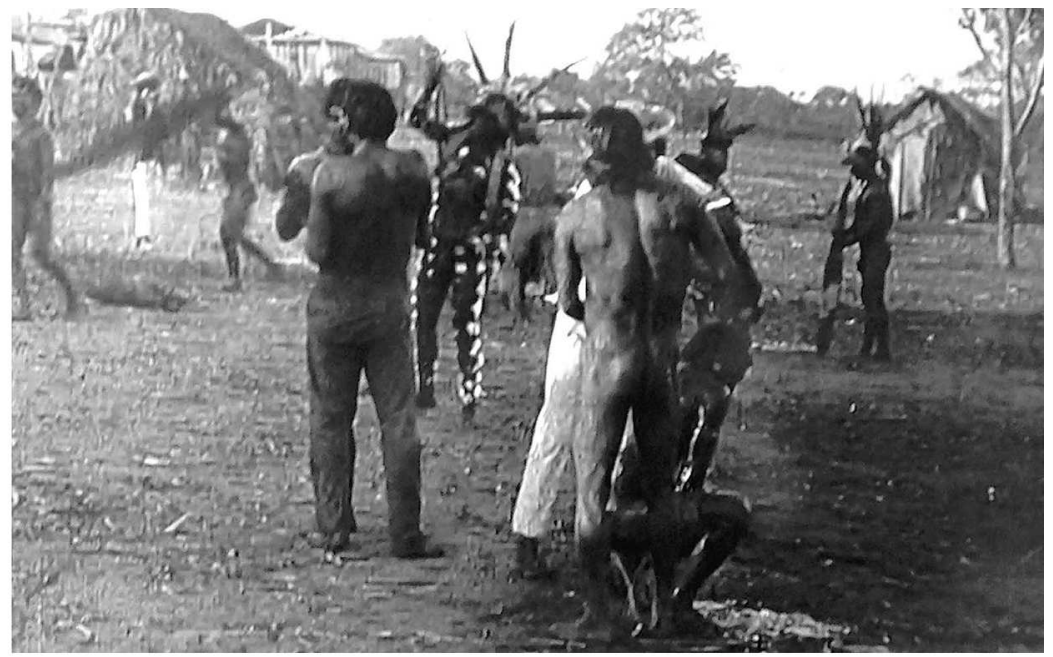

(b)

Figure 11 The aije bullroarer. (a) Example with clan design, as iilustrated by von den Steinen [1894: 498]. (b) As seen being operated in the middle distance by the ancestral spirit Bokwojeba (black body paint with tufts of white down), in a frame grab from the film. The bullroarer is visible only as a blur on the upper left of the screen. Another man, screen right, holds a large bullroarer in front of him at waist level (C) Acervo do Museo do Índio-FUNAI, Brazil).

masculinity and male reproductive power in Bororo ceremonial life. First, the spatial location of this ceremony is not just a randomly selected secluded spot nearby in the bush, as Reis's introductory intertitle implies, but rather a very specific place, known as the aije-muga, situated to the west of the village [Figure 9]. That it is to the west is no mere coincidence: rather it is because the west is strongly associated in the Bororo imaginary with masculinity, the dead, the setting sun and the ancestral spirit Bakororo, the player of the phallic-shaped $i k a$ flute, and is thus opposed to the area east of the village which is associated by contrast with femaleness, birth and fertility, the rising sun and the ancestral spirit Itubore, the player of the curvaceous, three-chambered panna trumpet.

Here, in the aije-muga, Reis shows a group of men engaged in what he describes in the intertitles as a "jaguar hunt," wherein those with mottled body decorations represent the spotted jaguar and those painted with mud represent the brown jaguar, while other men, without specific body decoration, are said to represent the hunters. But this interpretation is completely erroneous: in fact there is only one man with mottled body markings in shot and this is clearly the same man whose body decoration, consisting of black paint with spots of white down, identifies him not as the spotted jaguar but as the ancestral spirit Bokwojeba who earlier in the film had been shown whirling the phallic aije bull-roarer [Figure 11b]. Meanwhile, the several men who are shown being painted with mud represent not the brown jaguar but rather the ancestral spirit aije itself, supremely dangerous for women, and one of whose manifestations is a mythical animal that lives in water or in mud. ${ }^{24}$ Although the sequence ends with an enactment of some kind, this does not appear to be of a hunt as such, certainly not of 
animals by humans: on the contrary, it is Bokwojeba and the mud-painted aije spirits who, on their hands and knees and seemingly barking, appear to be pursuing the men with bows and arrows rather than vice versa [Figure 12].

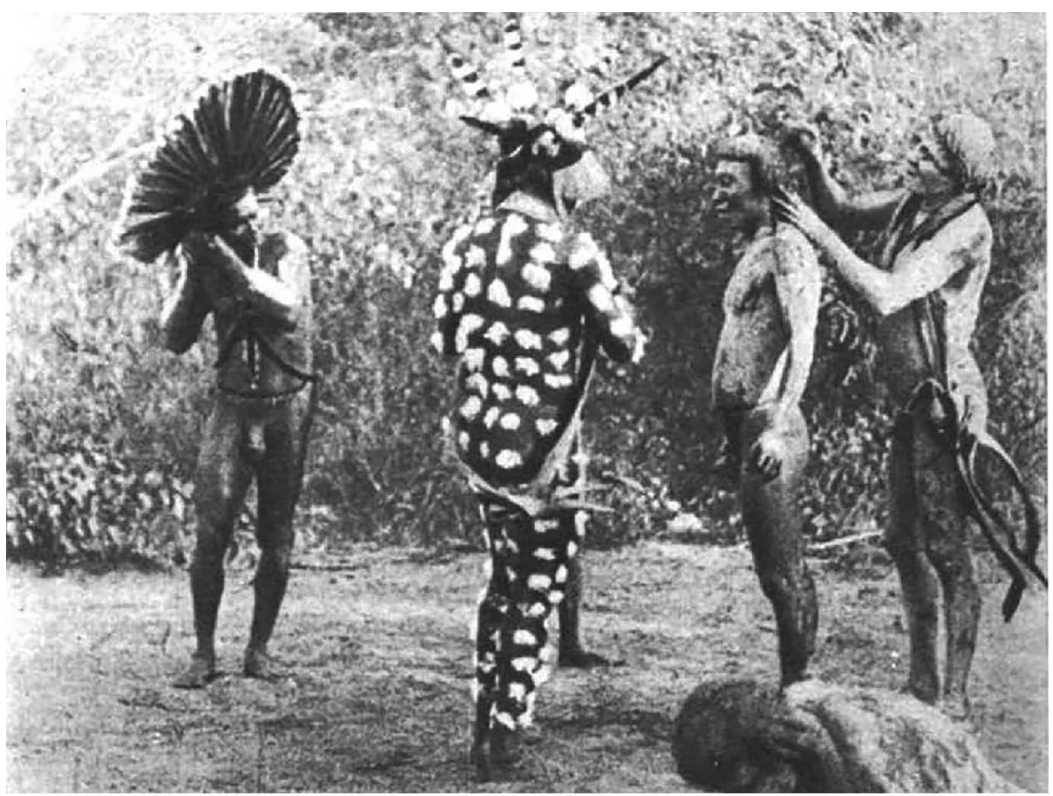

(a)

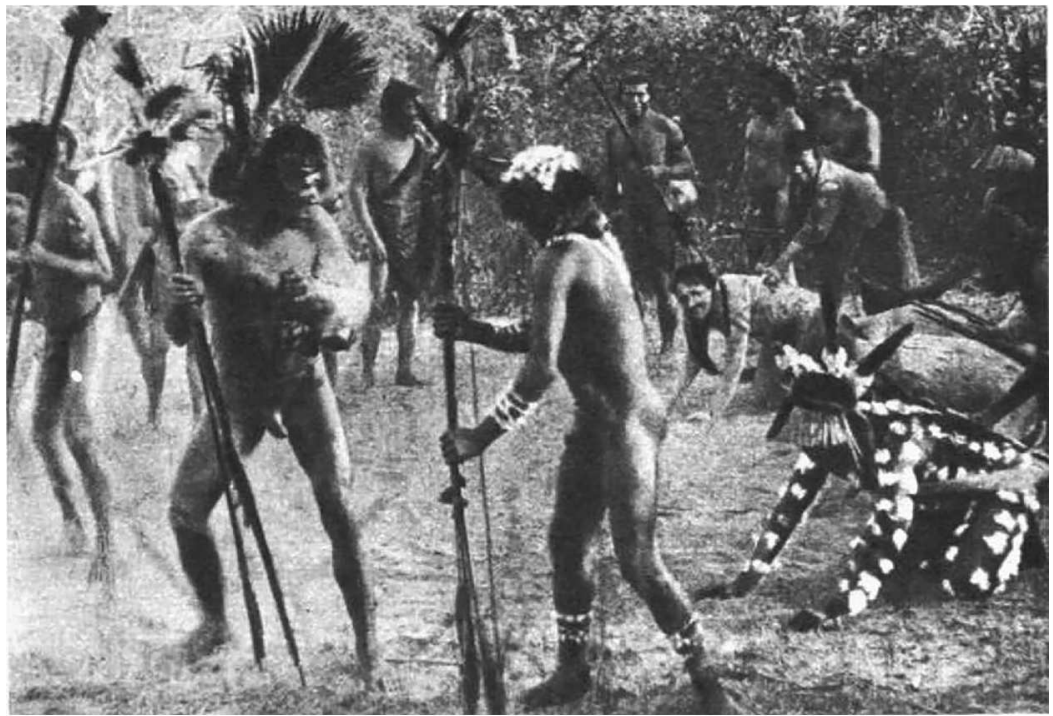

(b)

Figure 12 The aije ceremony. (a) The aije spirits are painted with mud. Bokwojeba represented by the man, center, with mottled body paint (Rondon 1946: 288; (C) Acervo do Museo do IndioFUNAI, Brazil). (b) Bokwojeba and the aije spirits pursue the "hunters" (Rondon 1946: 292; () Acervo do Museo do Índio-FUNAI, Brazil). 
There are various important absences too from this sequence dealing with the aije ceremony. First, there is no evidence of the intermoiety exchange of bullroarers that customarily takes places during the ceremony (though on careful inspection one can see a man moving around in the background holding a bullroarer). Nor is there any representation of the moment when the mud-painted men representing the aije spirit (known collectively as the aije-doge) go into the village plaza and women emerge from the houses with new-born babies so that the aije-doge can blow on them to give them strength. Also absent is the moment when, after dark, the aije-doge rub up against one another in a mock display of homoeroticism. But most importantly of all, there is no reference in this sequence to the initiation of boys that is an integral part of the aije ceremony and could even be considered its principal rationale. For, in the course of the ceremony, the initiands are shown the aije bull-roarers for the first time and then put on the $b a$, the penis sheath, indicating that they are now entitled to engender children. After the ceremony, they will go to live in the men's house in the center of the village.

There are many other features of the Bororo funeral that are shown in Rituais $e$ Festas Borôro about whose significance Reis was seemingly quite unaware; there are also many features that he neglected to film entirely. But clearly it would be absurd to criticize him for this: after all, he only remained in São Lourenço for a little over two months, and he was an army officer rather than a trained ethnographer; and though it is possible that he may have been extensively briefed about the Bororo funeral by Rondon there is no evidence to suggest that he had access to any prior studies based on a prolonged period of research. Instead we would argue that due to his great skill and sensitivity as a cinematographer one can still gratefully observe, through his film, the funeral being performed by a large number of people wearing traditional dress and personal ornamentation, to a degree that it is now no longer possible to witness at first hand.

There is perhaps no sequence of which this is more true than that following the event in which men from opposed moieties compete to balance the large circular $60 \mathrm{~kg}$ mariddo rings on their heads. In this sequence, which occurs about twothirds of the way through the film, two circles of dancers, perhaps fifty in total and all decked out in elaborate ceremonial dress, with many carrying powari-aroe, move in opposite directions around the mariddo, one circle of dancers within the other, in a great cloud of dust raised by their feet. Exquisitely filmed by Reis, these images capture the dynamism, vitality and beauty of the traditional Bororo funeral in a way that no text or still image could ever achieve [Figure 13].

However, while all the examples considered so far could be viewed as errors of omission, arising from Reis's perfectly understandable ignorance of Bororo religious ideas, his film also features what one might call errors of commission, i.e., instances where he has knowingly misrepresented the Bororo funeral as he witnessed it. These mainly relate to the fact that due to the lack of any means of artificial lighting, he was unable to film inside the men's house where some of the most significant moments in the Bororo funeral take place, including its culminating events.

Reis attempted to get round this technical problem by asking the "chief" who was responsible for organizing the ceremony-probably the ritual father of the aroe-maiwu - to allow him to cut a hole in the roof. He had even brought with 


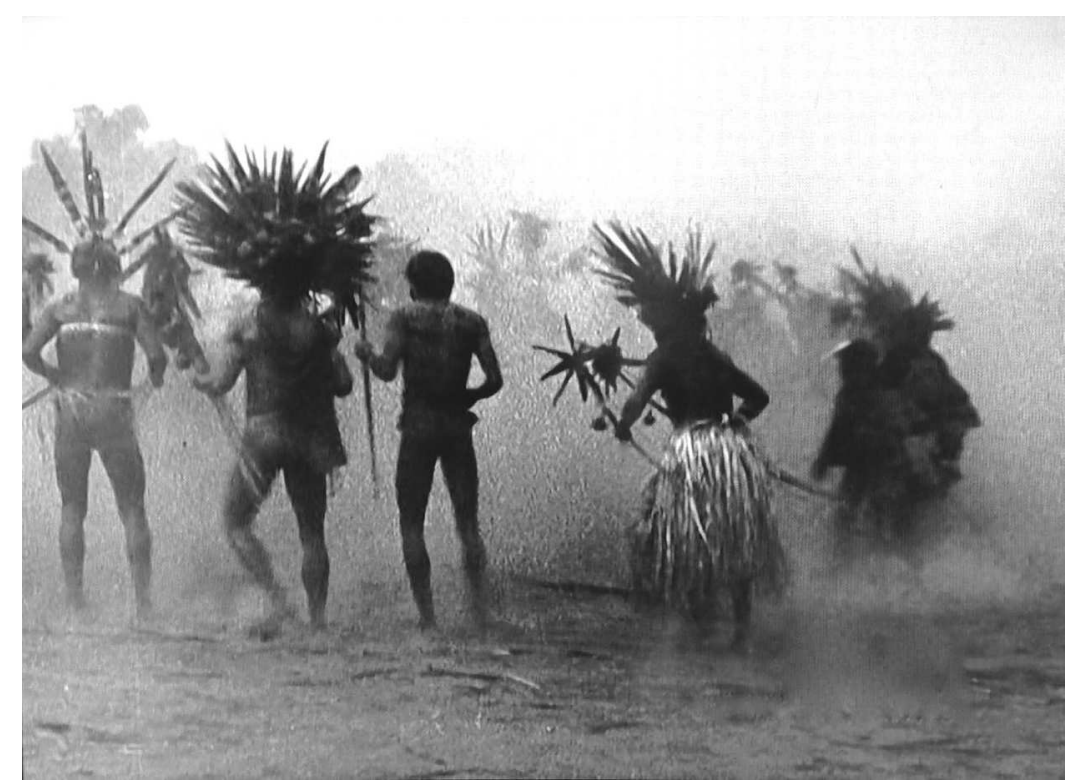

Figure 13 Dancing around the mariddo discs. The man in the foreground with palm-leaf skirt appears to be dressed in the manner of the aroe-maiwu, the representative of the deceased, while the bow staffs topped with bunches of feathers that he holds in each hand, and the small gourds, powari-aroe, hanging from the bows, also testify to the presence of the spirits of the dead. (Frame grab; (c) Acervo do Museo do Índio-FUNAI, Brazil)

him some rolls of white cloth that he could have used as reflectors to enhance the light that this would have allowed in. But the "chief" refused his request, fearing that the family of the dead woman would have regarded it as an act of disrespect. Bitterly disappointed, Reis remarks in his report that if there had been a different SPI manager his request would probably have been granted, thereby implying that if the current manager, Sr. Barbosa, had supported him, he might have been able to persuade the "chief" to change his mind [Reis 2011: 271-272, 278].

Being unable to film the culminating events inside the men's house, Reis appears to have decided in the editing suite to make the burial of the deceased woman out on the bororo into the climax of his film. ${ }^{25}$ But as he knew perfectly well, this involved a radical misrepresentation of the chronology of the funeral. For in reality the Bororo funeral traditionally involves two burials, of which the burial on the bororo is only the first. This usually takes place immediately following death and serves, in effect, as the trigger for all the other events that are presented in the film, not just all the dancing and other ritual events but also the collective fishing expedition and the making of the ritual paraphernalia that are presented early in the film. While all this is taking place, over the course of a month or so, the body is allowed to rot in its grave in the bororo, a process that is aided by regular dousing with water mixed with palm juice, starting with the dousing at the time of the first burial (as in Figure 2f). Finally, when all the flesh has decayed, the bones are exhumed and taken to be washed in a nearby lagoon. They are then returned to the village where they undergo various ritual procedures inside the men's house. 
This culminating phase of the funeral inside the men's house was first represented in an artist's impression that accompanied the written account of the ceremony published by von den Steinen in 1894 [Figure 14]. Notwithstanding certain ethnographic inaccuracies, not to speak of the cultural changes that have taken place in the interim, in the view of Caiuby, who has witnessed more than thirty Bororo funerals, this image conveys the general atmosphere of this ceremonial moment very well.

The most important act of this phase of the funeral consists in decorating the skull of the deceased with annatto and feathers in accordance with the designs associated with the deceased's clan. This is carried out by men of the moiety opposite to that of the deceased. In order to do so they normally sit behind a screen, since in decorating the bones they are considered to be transforming the deceased into an aroe, an ancestral spirit, a process that the Bororo believe should not be witnessed by women and children. (It is in this sense particularly that Figure 14 is ethnographically inaccurate.) When the decoration is complete the skull, together with the other bones, is placed in a basketry tray and returned to the women, who cradle the bones as if they were a baby, wailing as they do so. As they might also have done immediately post-mortem, close female relatives of the deceased may lacerate themselves and sprinkle the blood over the bones, thereby restoring to them a semblance of the flesh that has decayed. These

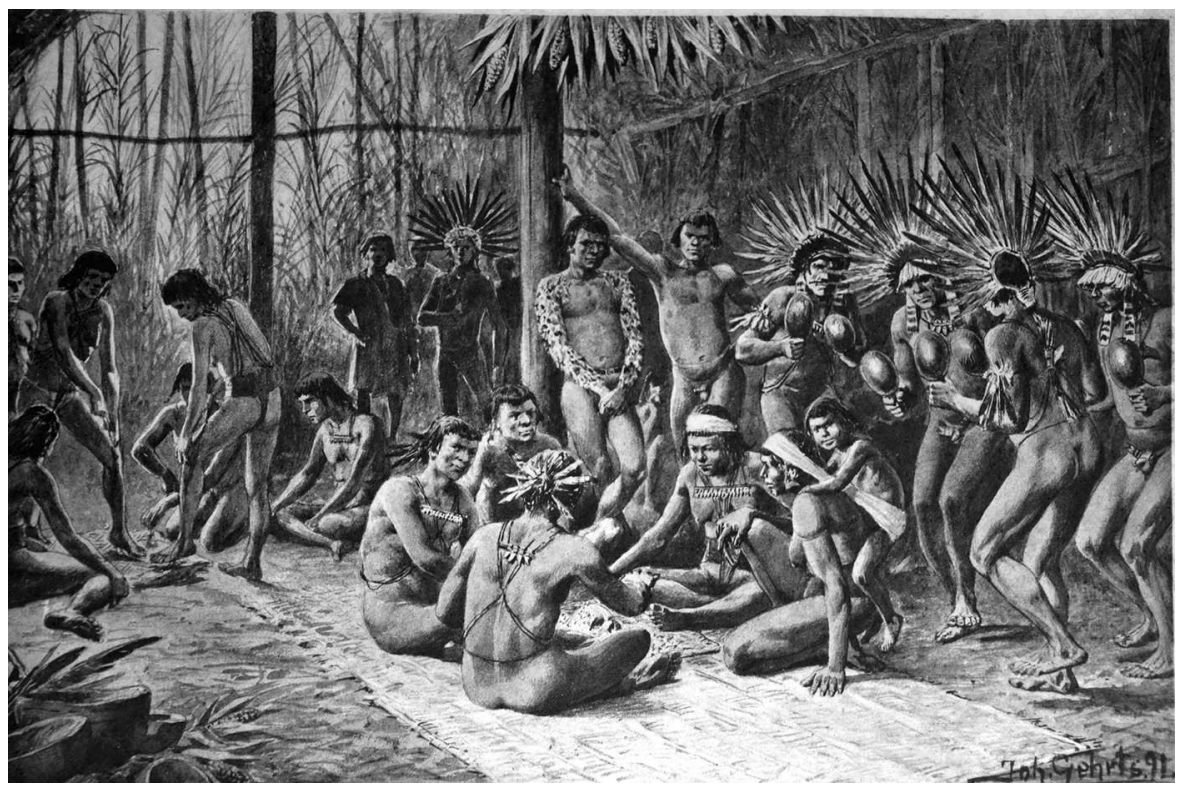

Figure 14 The culminating phase of the funeral inside the men's house, as illustrated by von den Steinen [1894: 504-505]. In the center the skull of the deceased is decorated with feathers, while to the left female relatives lacerate their legs, and to the right senior men are chanting. The arowemaiwu, with down on his arms, looks on from behind the central group. Although this artist's impression captures the atmosphere well, it involves a major inaccuracy: normally, the men decorating the skull are hidden behind a screen so that women and children may not see them. 
processes are accompanied by extended periods of chanting, led by senior ritual specialists. Finally, the bones are placed in a larger, enclosed basket, along with certain items of the dead person's ritual paraphernalia, and taken to the house of the ritual parents of the deceased, where they should "rest" for a week or so. They are then taken to the nearby lagoon, where they are lowered into the water, to their final resting-place. In this way the bones return to the realm of bope, the ancestral spirit controlling all life-cycle transformations [Caiuby Novaes 2006c: 60-71; 2008: 123-124].

Although Reis does not mention the decoration of the skull with feathers, nor the final submerging of the bones in the lagoon, he certainly witnessed other later phases of the funeral ceremony, including the disinterring and washing of the bones and the chanting inside the houses. The stripping of the bones of their flesh, he comments, "was a scene to make one's hair stand on end." The scene inside the men's house he found similarly challenging. The chanting of ritual specialists in their diadem headdresses, accompanied by the regular beat of their maracas, the clouds of dust raised by their feet, and the women calling out praises of the deceased as they slashed themselves with sharpened pieces of shell, he describes as "hellish and frightening," an "apocalyptic vision" [Reis 2011: 277-278].

Nevertheless Reis very much regretted that for lack of illumination he could not film these scenes, since he felt that not only would they have stimulated his blasé urban audiences greatly, but also because he believed that one could not say that one had any genuine knowledge of the Bororo unless one had been able to witness these scenes. In a strikingly rhetorical passage in the middle of his mostly matter-of-fact report, he observes:

The Bororo Indian, in all his ritual activity, is fervently and passionately sentimental. The play of the muscles in his face is remarkable: no academy of art holds sketches of such expressions, nor plaster casts that could come close to them, such is the strength of the lines rendered on their features when they are in thrall to their passions. Pain, despair, joy, laughter, greed, hate, love, jealousy, in short, everything that the human face can express in the most intimate of moments, the Bororo reproduce in the course of their rituals. [Reis 2011: 272, trans.]

Reis goes so far as to claim that a film that showed the Bororo performing their ritual activities inside their houses would be unprecedented in the genre of "film do natural," i.e., non-fiction filmmaking, and that no film would be better received or admired. But, he ruefully concludes, probably only Rondon himself would have been able to persuade the Bororo to allow in sufficient light for such scenes to be filmed [Reis 2011: 279]. ${ }^{26}$

\section{RONDON'S CINEMATOGRAPHER}

As Reis does not discuss the editing of Rituais e Festas Borôro in his report, nor anywhere else to the best of our knowledge, we can only speculate as to his precise reasons for altering the chronology of the event so radically. For not only does he displace the burial scene from the beginning of the ceremony to the end of the film, but he has also clearly altered the chronological order of the various 
dances and other events shown in between: at first, the rolled up mat containing the corpse is present, then it disappears, then it reappears again. We see the dancers being doused with water over the point in the bororo where the body appears to have been buried long before we see the body actually being buried at the end of the film. The final dance in the film, for which the dancers are carrying branches of leaves, normally takes place midway through the period of dancing. And so on: many further examples of these chronological manipulations could be given. ${ }^{27}$

It is possible that his reasons for altering the chronology in this way were purely editorial. As we have noted, he had a keen sense of the need to entertain his audiences, and clearly a film that ended without a suitable climax or merely with an intertitle reference to an event that could not be filmed for technical reasons would have been a disappointment to those audiences. However, given the role of film as a propaganda instrument of the Rondon Commission and the commitment of Rondon himself to the notion that the indigenous inhabitants had played an admirable role in the formation of Brazilian identity, it may also have seemed advisable to end the film with a burial scene that would be readily recognizable by the culturally European urban cinemagoers who would be the primary audience. Certainly this would have been far more amenable to that audience than any reference to matters that might have made their hair "stand on end." However, all this can only be a matter of speculation since, to our regret, we have no information as to how the film was received by contemporary audiences. ${ }^{28}$

But whatever the precise reasons for this editorial decision, what is certainly the case is that Reis never again made a film based on an extended period of participation in the life of an indigenous community. Immediately after Rituais $e$ Festas Borôro he shot a film for a major rubber-tapping company in exchange for the logistical support which that company, Asensi, had rendered to the Commission. Reis had a high opinion of this film, which he entitled Ouro Branco (literally "White Gold," referring to the economic value of the latex), but it now appears to be lost [Portugal Lasmar 2011: 153]. Then, in 1918, he traveled to the United States at the invitation of the National Geographic Society in order to screen a film with an English-language title, Wilderness, clearly designed to link it to Through the Brazilian Wilderness, Roosevelt's textual account of his expedition with Rondon [1914]. This film too appears to be lost, but according to Reis's account of his visit it had five or possibly six parts: one about Rio de Janeiro and São Paulo, another about the Roosevelt-Rondon Expedition, and a third that had also featured in Os Sertões, showing the Paresi Indians playing a game with a ball made of natural rubber. The other parts seem to have been extracts from Rituais e Festas Borôro [Lobato 2015: 310; Rodrigues 1982: 2-3].

Although Wilderness was screened at Carnegie Hall in New York in the presence of Theodore Roosevelt himself, Reis failed to achieve the commercial distribution that he was seeking for the film in the United States [ibid.: 311-314]. In 1920, to ensure that the film gained commercial distribution in Brazil, he gave the film a Portuguese-language title, De Santa Cruz, and cut it into five parts, adding two new parts, one about a jaguar hunt, another about the Iguazu Falls, both of which he had shot on the way back from São Lourenço in 1916. Whether he removed the Bororo material in order to insert these two new parts is unclear, 
but it seems quite possible given that this version of the film has been described as being "less scientific" than Wilderness [Rodrigues 1982: 3]. Reis would certainly not be the only filmmaker to have discovered that ethnographic film does not necessarily do well at the box-office, no matter how skillfully it has been made. ${ }^{29}$

Through the 1920s Reis continued to make expedition films, often in conjunction with Rondon, who had by now been appointed head of the Inspectorate of Frontiers. Reis traveled all over Brazil with him, including to the frontiers with French Guiana and Venezuela in the north, and to various points along the frontiers with Bolivia and Paraguay in the southwest. He also accompanied Rondon when the latter was sent to the Brazilian Northeast to co-ordinate government efforts to combat a severe drought, and again when Rondon was appointed to lead the campaign to put down a military insurrection in Paraná State, in the south of the country. On both of these latter occasions, Reis appears to have made a film, but no known copy of either film exists [Sá Pereira 1982: 10-11].

Although indigenous people sometimes appear briefly in some of these films on account of Rondon's particular interest in such groups, so too do many other subjects, both human and environmental. In 1924 Reis made a film as a member of a scientific expedition to Central Brazil that was not led by Rondon but rather by a certain Capt. Vicente Vasconcelos [Reis 1945]. This also included a few sequences of Xinguano indigenous people, but again along with many shots of geographical features, animal life and the general progress of the expedition. In the excruciating final sequence the handsome Xinguanos are shown being dressed in brand new SPI uniforms that are far too big for them, as if it were a triumph of civilization over savagery. This material, along with material from several of Reis's other expeditionary films, was later compiled into the feature film, Ao Redor do Brasil, released in 1932 and running to eighty minutes. ${ }^{30}$

In 1934, when Rondon left the Frontier Inspectorate and was replaced by another army officer with much less interest in indigenous groups, Reis, by now promoted to the rank of Major, continued to work with the service, but indigenous people still living a traditional way of life assumed an even lower profile in his films. His final film, Inspetoria Especial de Fronteiras, released in 1938 , is an over-long expedition film of 99 minutes, mostly composed of entirely forgettable sequences of parades of soldiers and highly acculturated indigenous schoolchildren at various Salesian mission stations along the Upper Rio Negro. Only in the last few minutes does the film offer us some images of an indigenous group, the Tuyuka, engaging in a traditional dance. But this is accompanied by a series of intertitles reassuring the viewer that civilization is on its way, in the form of the Salesians. Not long afterwards, in 1940, both Reis's life and his career came to a tragically premature end, when he was 61 years of age. Whilst filming the demolition of an army barracks in Rio de Janeiro he was struck by a falling wall and died in hospital some weeks later [Rodrigues 1982: 5].

There is no evidence to suggest that in the course of his lifetime Reis was ever aware that, in making Rituais e Festas Borôro, he had produced a work of any great importance. It was a film that came about as a result of a certain concatenation of circumstances that would never again arise in the course of his career. For, as one of the few published profiles of Reis puts it, he was first and foremost the "cinegrafista de Rondon, “31 that is, Rondon's cinematographer, and when Rondon's 
interests moved on from the Bororo and Mato Grosso to the inspection of frontiers, the relief of drought and the putting down of a military rebellion, so too did his own. When he worked with other expedition leaders who did not share Rondon's interest in the traditional culture of indigenous peoples, only rarely did Reis film sequences on this subject and usually then only in the most superficial and descriptive fashion.

It is somewhat ironic that a filmmaker with seemingly little personal interest in ethnographic topics should have produced what is undoubtedly one of the early masterworks of ethnographic cinema. But if the making of this film featured a prolonged commitment to the recording of a complex form of cultural expression by one particular human group that was unusual, possibly unprecedented at that time, this was not a reflection of Reis's own personal interests. Rather it was a reflection of the interests of the person who in all probability had given Reis the initial instruction to make the film. This was Cândido Mariano da Silva Rondon, for whom Rituais e Festas Borôro would have represented not merely a celebration of his own indigenous roots and his sense of Brazilian identity but also a defiant rejection of the missionaries' evangelization.

Yet none of this should prevent us from according Luiz Thomaz Reis a special place in the history of ethnographic cinema; for there is surely no doubt that Rituais e Festas Borôro is the work of a highly accomplished filmmaker, in both a technical and an aesthetic sense. It is also a film of particular significance in that it would appear to hold a strong claim to be considered the very first ethnographic documentary to be made, not just in Brazil, but anywhere in the world, exactly one century ago.

\title{
ACKNOWLEDGMENTS
}

\begin{abstract}
Henley would like to thank Rodrigo Piquet Saboia de Mello and his colleagues at the library of the Museu do Índio, Rio de Janeiro, for the support that he received while carrying out research on the films of Luiz Thomaz Reis. All three authors also thank Peter Blore, the Senior Designer of the University of Manchester Graphics Support Workshop, for his work on Figures 1 and 9 of this article, and Ricardo Dionisio of the Laboratorio de Imagem e Som em Antropologia (LISA) at the Universidade de São Paulo (USP) for his work on the reproduction of the von den Steinen images in Figures 8, 10 and 13.
\end{abstract}

\section{FUNDING}

Caiuby Novaes holds a research grant from CNPq 2015-2018 [308257/2014-6], while Cunha holds grant 2008/564386 from FAPESP. Henley would like to acknowledge the support of the Leverhulme Trust in the form of the Major Fellowship that enabled him to carry out research into early ethnographic film, including in Brazil.

\section{NOTES}

1. The orthography of Brazilian Portuguese underwent a major change in 1938. Following conventional practice, for film titles and personal or institutional names in use prior to that date, we shall adopt the standard orthography of the time. Geographical names, on the other hand, have all been rendered in the modern form, except when used in a film title, e.g., Os Sertões de Matto-Grosso. 
2. Rituais e Festas Borôro has recently been made available on-line at https://www. youtube.com/watch?v=Ein6eKqMBtE by the Museu do Índio, Rio de Janeiro. Copies of the film on DVD, at modest cost, are also available from the Museu: write to nubarq@museudoindio.gov.br.

3. Steinen's text has been republished in Portuguese [1940], while Lévi-Strauss's text has been republished in English [1973].

4. The footage shot by Dina Lévi-Strauss was blown up to $16 \mathrm{~mm}$ and presented in a film directed by Jean-Pierre Beaurenaut, Jo Bodanzky and Patrick Menget [1991], included in our Filmography.

5. Sylvia Caiuby Novaes has published much relating to the Bororo funeral, including Caiuby Novaes [1994, 1997, 2006a, b, c, 2008 and 2016], while relevant publications by Cunha include Cunha [2006, 2009, and 2010]; cf. also the film by Cunha [2005] in the Filmography.

6. The only other filmic account of the Bororo funeral under traditional circumstances that comes close to Reis's film in terms of the complexity of the performance represented is a body of material produced in 1953 by Heinz Förthmann and Darcy Ribeiro in Córrego Grande, a village very close to the by-then abandoned site where Reis had worked. Sadly, however, the editing of the Förthmann and Ribeiro material was never completed, much of the original footage and the sound recordings appears to have been lost, and today it is available only in the form of a set of largely mute and chronologically jumbled rushes [Mendes 2006: 269-319; 2011: 246].

7. The official title of the Commission was actually "Commissão de Linhas Telegráficas e Estratégicas do Matto Grosso ao Amazonas." Partly on account of the daunting acronym-CLTEMGA - and partly due to Rondon's high personal profile, it is almost invariably referred to, both in historical sources and in present-day literature, as the "Rondon Commission."

8. The distinction between "catechization" and "protection" was sometimes blurred by the practice of referring to the latter as catequese leiga, "lay catechization."

9. For a much more sceptical account cf. Langfur [1999], who argues that although Rondon's policy of nonviolence may have had some immediately positive effects, the construction of the telegraph lines encouraged an intensification of the invasion of Bororo territory, resulting in the Bororo being displaced from their lands and greatly increasing rates of mortality due to imported diseases.

10. Rondon described the funeral as the ritual event "que mais empolga os bororos," which could be translated as "that most entrances the Bororo" [Viveiros 1958: 133].

11. Only three years prior to the creation of the SPI, Hermann von Ihering, a distinguished zoologist and director of the Museu Paulista, one of the most important scientific institutions in Brazil at the time, published an article arguing for the need to exterminate the Kaingang, who were becoming a hindrance to the colonization of the interior of the State of São Paulo and the building of a railway line [Ihering 1907]. Rondon and other leading figures of the Positivist movement joined together in vigorously denouncing these genocidal attitudes [Hemming 1988: 16-18; Ribeiro 1996: 149-151].

12. Their population, perhaps 15,000 at first contact, had declined to around 10,000 by the start of the 20th century, and perhaps reached a mere 500 in the 1960s. Since then it has increased again, however: official sources have counted 1,817 Bororo in 2014. One of the authors of this article, Caiuby Novaes, has made around forty field trips to Bororo villages since the 1970s and on almost all of them she witnessed a funeral. Similarly, between 2000 and 2005, Cunha made eight field trips to Bororo villages and saw a funeral on every visit. 
13. These production stills also include two images of the Bororo wearing what appear to be elaborate 19th-century military uniforms, leading us to wonder whether these might not have been among the contents of the boxes of gifts that Reis brought with him.

14. Caiuby Novaes saw men wearing the penis sheath on an everyday basis as late as the 1970s. By the early 2000s everyday use had been abandoned, but as observed by Cunha, boys were still putting on penis sheaths in the course of their initiation ceremonies.

15. There is one possible exception to this: midway through the film, shortly after the intertitle announcing that women are now permitted to join the dancing, there are three brief shots of a circular dance in which men and women alternate in the line of dancers. Right at the end of the line, in the appropriate female position, i.e., between two male dancers, there is a dancer apparently wearing a traditional girdle, whose hands are cupped under the breasts in the typically female manner. However, strangely, this dancer is wearing a sort of shawl obscuring the head, while the dancer's physique suggests that "she" is in fact a man!

16. As one leading missionary wrote: "I thought I might succeed in hindering them from performing those horrible mortuary ceremonies... my hopes lay in the fact that though they might want to resume their custom, they would tire since there were about thirty dead: but it was not so." [Bálzola 1932: 157; trans. from Italian and cited by Caiuby Novaes 1997: 82].

17. A detailed recent summary account of the Bororo funeral, readily available and extensively illustrated with many contemporary photographs and diagrams, is to be found in Caiuby Novaes [2016: 93-97].

18. Reis also refers to the "men's house" as the bahyto, a term that in various forms is often reproduced in the ethnographic literature; but this usage is also based on an error: in fact, the term used by the Bororo themselves is bai mana gejewu, literally "central house." In the idealized village layout represented in Figure 9, which is based on the diagram prepared by the Salesian missionary ethnologists Albisetti and Venturelli [1962: 436], this structure is located in the exact center of the village, while in practice it tends to be offset in one direction or another, so that the bororo dancing and burial ground in effect constitutes the center of the village.

19. See the photographs of the aroe-maiwu in Caiuby Novaes [2016: 97, 107].

20. As described above, Rondon offered a jaguar skin to the deceased's relatives at one of the funerals he attended [Viveiros 1958: 357-358].

21. The range and complexity of the aroe-etawaujedu are considerable. In the Enciclopédia Bororo, Albisetti and Venturelli describe over sixty different forms of representing ancestral spirits, each with a particular type of body painting, adornment, headdresses, dance movement, and vocalizations [Albisetti and Venturelli 1962: 120-162].

22. In fact there seem to be several aroe-maiwu in the film. These individuals are not singled out as such by Reis, but they may be identified by their distinctive dress. This suggests to us that although Reis mentions the death of only one woman (and also of a baby, though babies are commemorated through such a funeral only after being named) and shows only one corpse being buried, it may be that several recently deceased people were being commemorated at this funeral. This is not uncommon at Bororo funerals and, if this were the case, it would explain why it is that while some dancers are carrying a tray-like basket in front of them, which is the symbol associated with a recently deceased woman, others are carrying symbols associated with a recently deceased man, notably bows with bunches of feathers attached to the end.

23. For a discussion of the many different meanings of the term aije, see Caiuby Novaes [1994]. 
24. When modern Bororo have gone to the zoo in São Paulo with Caiuby Novaes they have identified hippopotamuses and rhinoceroses as aije because they like to wallow in mud or water. Mud is also the place where aije bull-roarers are kept when not in use, in order to hide them from women, and where they are thought to build up the resistance necessary to be whirled. Mud is also the dwelling place of the bope, the ancestral spirit responsible for all human life-cycle transformations, including birth, puberty and death.

25. We have no direct evidence that Reis himself edited the film in the form that it has come down to us: like all other commentators, we merely assume this to be the case. Some grounds for doubt lie in the fact that the restored version of the film that is currently distributed by the Museu do Índio is "presented by" the Conselho Nacional de Proteção aos Indios [CNPI], an organization which only came into existence in 1939. However, from a detailed study of the intertitles, which are in the antique orthography used in Brazil until 1938, we believe that the most likely scenario is that the CNPI merely restored the film and inserted the "presented by" title at the beginning of the film without altering its overall structure.

26. On this last matter, Reis turned out to be entirely right; for the first time that the Bororo did allow these interior scenes to be filmed was almost forty years later, and then only at the specific request of Rondon himself. In 1953 Heinz Forthman and Darcy Ribeiro went to Córrego Grande to film the funeral of one of Rondon's closest Bororo associates, the great chief Cadete. As Rondon was almost ninety and unable to attend himself, he sent an audio recording, in Bororo, asking the Bororo to treat Ribeiro as if he were himself, since Ribeiro would be acting as his eyes, ears and mouth at the ceremony. When the Bororo heard the recording, Ribeiro later recalled, "they were very moved to hear his voice, it was Rondon, the grandson of a Bororo, and he was speaking Bororo-they were very emotional-and it was then that we began to document the ceremony" [Mendes 2006: 272, trans.; see also Caiuby Novaes 2006c: 60-71].

27. The stills from Reis's footage as they appear in Índios do Brasil are presented in a very different order [Rondon 1946: 248-297]. Here the burial scene comes closer to the beginning of the sequence of images, suggesting that this sequence may follow more precisely the order in which the images were shot in reality, though clearly there is no guarantee of this.

28. To the best of our knowledge the only academic publication relating to the distribution of Reis's films is a recent online article by Ana Lobato [2015]. This however deals only with the films that were distributed commercially to cinemas, which did not include Rituais e Festas Borôro.

29. There is a discrepancy among the sources as to the number and nature of the parts in De Santa Cruz. Here we have followed the information given by Rodrigues in the Embrafilme pamphlet about Reis's work [1982]. However, Portugal Lasmar [2011: 149] suggests that when Reis took Wilderness to the United States the Iguazu and jaguar-hunting sequences already formed two parts of the six-part film and that there was only one part on the Bororo funeral. She does not however discuss the subsequent reduction of the film to five parts in 1920.

30. This film is available on YouTube at https://www.youtube.com/watch?v=k1j06p YHmiw.

31. O cinegrafista de Rondon is the subtitle of a pamphlet about Reis, written primarily by João Carlos Rodrigues and published by the now-defunct Brazilian national film distribution company, Embrafilme [1982]. 


\section{REFERENCES}

Albisetti, César, and Ângelo Jayme Venturelli

1962 Enciclopédia Bororo. Vol. 1: Vocabulários e Etnografia. Campo Grande, Mato Grosso: Museu Regional Dom Bosco.

Bálzola, Giovanni

1932 Don Bálzola fra gli Indi del Brasile-Matto Grosso. Note autobiografiche e testimonianze raccolte da D. A. Cojazzi. Turin: Società Editrice Internazionale.

Botelho de Magalhães, Amilcar

1926 Impressões da Commissão Rondon. 3rd edn. Porto Alegre: Livraria do Globo.

Caiuby Novaes, Sylvia

1983 As casas na organização social do espaço Bororo. In Habitações Indígenas. Sylvia Caiuby Novaes, ed. Pp. 57-76. São Paulo: Nobel and EDUSP.

1994 Aije-a expressão metafórica da sexualidade entre os Bororo. Revista de Antropologia, 37: 183-201.

1997 The Play of Mirrors: The Representation of Self Mirrored in the Other. Austin: University of Texas Press.

2006a Bororo Funerals: Images of the Refacement of the World. Tipití, 4: 177-198.

2006b Plaits, Gourds and Jaguar Skins in the Bororo Funeral-toward an Understanding of the Bororo Notion of Person. Vibrant (Florianópolis), 3(1): 27-36. (Available online at http:/ / www.vibrant.org.br/issues/v3n1/sylvia-caiuby-novaes-plaits-gourds-and-jaguarskins-in-bororo-funeral/)

2006c Etnografia visual-sobre o impacto das imagens na etnografia do funeral Bororo. In Etnografia Visual. Tese de livre docência. By Sylvia Caiuby Novaes. São Paulo: FFLCH-USP

2008 Corpo, imagem e memória. In 8 X Fotografia. Lorenzo Mammi and Lilia Schwarcz, eds. Pp. 113-131. São Paulo: Companhia das Letras.

2016 Iconography and Orality: on Objects and the Person among the Bororo. Revista GIS, 1(1): 88-115. (Available online at http://revistas.usp.br/gis/article/view/116351/114062)

Colbacchini, Antonio

1925 I Bororo Orientali "Orarimugudoge" del Matto Grosso [Brasile]. Contributi Scientifici delle Missioni Salesiani del Venerabile Don Bosco. Turin: Società Editrice Internazionale.

Crocker, Jon Christopher

1985 Vital Souls: Bororo Cosmology, Natural Symbolism, and Shamanism. Tucson: University of Arizona Press.

Cunha, Edgar Teodoro da

2000 Cinema e imaginação: a imagem do índio no cinema brasileiro dos anos 70. São Paulo: Universidade de São Paulo, dissertação de Mestrado.

2001 Índio imaginado: cinema, identidade e auto-imagem. Cadernos de Antropologia e Imagem, 12: 39-50.

2006 Funeral Bororo em imagens: Major Reis e outros realizadores. In Estudos de Cinema Socine VII. Rubens Machado Jr., Rosana de Lima Soares and Luciana de Araújo, eds. Pp. 217224. São Paulo: Annablume.

2009 Comunicação, tradução e alteridade: imagens e pesquisa entre os Bororo do Mato Grosso. In Imagem-Conhecimento: Antropologia, Cinema e outros diálogos. Edgar Teodoro Cunha, Andréa Barbosa, and Rose Satiko Hikiji, eds. Pp. 177-198. São Paulo: Papirus.

2010 Images and Research among the Bororo of Mato Grosso, Brazil. Visual Anthropology, 23: 311-329.

Freire, Carlos Augusto da Rocha

2011 A iconografia indigenista: imagens de uma história de confrontos. In Memória do SPI: textos, imagens e documentos sobre o Serviço de Proteção aos Índios (1910-1967). Carlos Augusto da Rocha Freire, ed. Pp. 14-53. Rio de Janeiro: Museu do Índio-FUNAI

Hemming, John

2003 Die if You Must: Brazilian Indians in the Twentieth Century. New York: Macmillan.

Henley, Paul

2013 Thick Inscription and the Unwitting Witness: Reading the Films of Alfred C. Haddon and W. Baldwin Spencer as Ethnographic Documents. Visual Anthropology, 26(5): 383-429. 
Ihering, Hermann von

1907 A anthropologia do Estado de São Paulo. Revista do Museu Paulista, 7. (Available at http:// etnolinguistica.wdfiles.com/local-files/biblio\%3Aihering-1907-anthropologia/ihering 1907_anthropologia_archive.pdf)

Jordan, Pierre-Léonce

1992 Cinéma: Premier contact—premier regard. Marseilles: Musées de Marseille/Images en Manoeuvres Éditions.

Langfur, Hal

1999 Myths of Pacification: Brazilian Frontier Settlement and the Subjugation of the Bororo Indians. Journal of Social History, 32(4): 879-905.

Lévi-Strauss, Claude

1973 Tristes Tropiques. London: Penguin. (First published in French by Librarie Plon in 1955.)

Lima, Antonio Carlos de Souza

2011 Reconsiderando poder tutelar e formação do Estado no Brasil: notas a partir da criação do Serviço de Proteção aos Índios e Localização de Trabalhadores Nacionais. In Memória do SPI: textos, imagens e documentos sobre o Serviço da Proteção aos Índios (1910-1967). Carlos Augusto da Rocha Freire, ed. Pp. 201-211. Rio de Janeiro: Museu do Índio-FUNAI.

Lindstrom, Lamont

2016 Shooting Melanesians: Martin Johnson and Edward Salisbury in the Southwest Pacific. Visual Anthropology, 29(4-5): 360-381.

Lobato, Ana

2015 Da exibição dos filmes da Comissão Rondon. Doc On-line, 18: 300-322. (Available online at http://doc.ubi.pt/18/artigos_5.pdf)

Mendes, Marcos de Souza

2006 Heinz Forthmann e Darcy Ribeiro: Cinema Documentário no Serviço de Proteção Aos Índios, SPI, 1949-1959. Doutorado em Multimeios. Instituto de Artes. Universidade Estadual de Campinas.

2011 Heinz Förthmann: fotografia e cinema no SPI-1942/1959. In Memória do SPI: textos, imagens e documentos sobre o Serviço da Proteção aos 凶ndios (1910-1967). Carlos Augusto da Rocha Freire, ed. Pp. 233-253. Rio de Janeiro: Museu do Índio-FUNAI

Piault, Marc-Henri

2000 Anthropologie et cinéma: Passage à l'image, passage par l'image. Paris: Éditions Nathan.

Portugal Lasmar, Denise

2011 O Acervo Imagético da Comissão Rondon: no Museu do Indio 1890-1938. 2nd edn. Rio de Janeiro: Museu do Índio-FUNAI.

Reis, Luiz Thomaz

1945 Relatório. In his Expedição ao Rio Ronuro. Pp. 97-116. (Conselho Nacional de Proteção aos Índios, publication no. 90). Rio de Janeiro: Imprensa Nacional.

2011 Relatório. In O Acervo Imagético da Comissão Rondon: no Museu do Indio 1890-1938. 2nd edn. By Denise Portugal Lasmar. Pp. 266-310. Rio de Janeiro: Museu do Índio.

Ribeiro, Darcy

1996 Os Índios e a Civilização. A integração das populações no Brasil moderno. 7th edn. São Paulo: Companhia das Letras.

Rodrigues, João Carlos (ed.)

1982 Major Luiz Thomaz Reis: o cinegrafista de Rondon. Rio de Janeiro: Embrafilme.

Rondon, Cândido Mariano da Silva (ed.)

1946 Índios do Brasil—do Centro, Noroeste e Sul do Mato Grosso. Vol. 1. Conselho Nacional de Proteção aos Índios, Ministério de Agricultura. Rio de Janeiro. (Available online via the Museo do Índio, Rio de Janeiro, at http://www.docvirt.com/docreader.net/DocReader. aspx?bib=museudoindio\&pagfis $=$ )

Roosevelt, Theodore

1914 Through the Brazilian Wilderness. New York: C. Scribner's Sons.

Sá Pereira, Nellie

1982 Filmografia de Luiz Thomaz Reis. In Rodrigues [1982: 9-11]. 
Steinen, Karl von den

1894 Unter den Naturvölkern Zentral-Brasiliens. Reiseschilderung und Ergebnisse der zweiten Schingú-Expedition 1887-1888. Berlin: Dietrich Reimer. (Translated and re-published in 1940 as Entre os Aborígenes do Brasil Central. Separata da Revista do Arquivo Municipal, ns. 34-58. São Paulo: Departamento de Cultura.)

Tacca, Fernando de

2001 A imagética da Comissão Rondon-Etnografias fílmicas estratégicas. Campinas: Papirus.

2002 Rituaes e festas Bororo. A construção da imagem do índio como "selvagem" na Comissão Rondon. Revista de Antropologia, 45(1). (Available on-line at http:/ /www.scielo.br/scielo. php?script=sci_arttext\&pid=S0034-77012002000100006)

Vangelista, Chiara

2008 Politica tribale: Storia dei Bororo del Mato Grosso, Brasile. Vol. 2: Le alleanze (sec. XIX-XX). Turin: Il Segnalibro.

2014 Imagens, narrações, sensibilidades: representações dos índios no Brasil, do começo do século XX. In Escritas da História: Ver, Sentir, Narrar. Rosangela Patriota and Alcides Freire Ramos, eds. São Paulo: HUCITEC Editora.

Viveiros, Esther de

1958 Rondon conta sua vida. Rio de Janeiro: Livraria São José.

\section{FILMOGRAPHY}

Beaurenaut, Jean-Pierre, Jorge Bodanzky, and Patrick Menget

1991 A propos de Tristes Tropiques. Paris: Les Films du Village/La Sept/CNC; 46 min., color.

Cooper, Merian C., and Ernest B. Schoedsack

1925 Grass: A Nation's Battle for Life. Hollywood: Paramount Pictures; 63 mins., b \& w, silent.

Cunha, Edgar Teodoro da

2005 Ritual of life (Ritual da vida). Laboratório de Imagem e Som em Antropologia/Universidade de São Paulo; 30 mins., color.

Flaherty, Robert

1922 Nanook of the North. Paris: Revillon Frères; 55 mins., b \& w, silent.

1926 Moana: A Romance of the Golden Age. Hollywood: Famous Players-Lasky Corporation; 85 mins., $\mathrm{b} \& \mathrm{w}$, silent.

Griaule, Marcel

1940a Au pays des Dogon. Paris: Société de Films Sirius; 11 mins., b \& w. (Re-released in 2010 by Éditions Montparnasse (Paris) in the DVD collection Jean Rouch: une aventure africaine, but with an erroneous original release date.)

1940b Sous les masques noirs. Paris: Société de Films Sirius; 9 mins., b \& w. (Re-released in 2010 by Éditions Montparnasse (Paris) in the DVD collection Jean Rouch: une aventure africaine, but with an erroneous original release date.)

O'Reilly, Patrick

1970s Bougainville-îles salomon. Paris: Comité du film ethnographique (Musée de l'Homme) and Centre National de Recherche Scientifique; 38 mins., b \& w. (Originally shot in 1934-1935, and edited in a mute version. The sound version, with a voice-over commentary by Father O'Reilly, was produced in the early 1970s. Available in the CNRS Videothèque, at http:/ / videotheque.cnrs.fr/index.php?urlaction=doc\&id_doc=403\&rang=1)

Reis, Luiz Thomaz

1913 Os Sertões de Matto-Grosso. Rio de Janeiro: Commissão Rondon; unknown duration [lost], b \& w.

1914 Expedição Científica Roosevelt-Rondon. Rio de Janeiro: Commissão Rondon; unknown duration [lost], b \& w.

1917 Rituais e Festas Borôro. Rio de Janeiro: Conselho Nacional de Proteção aos Índios; 31 mins., b \& w.

1918 Wilderness. (Compilation film, re-cut and re-released in 1920 as De Santa Cruz.) Unknown duration [lost], b \& w.

1932 Ao Redor do Brasil. Aspectos do Interior e das Fronteiras Brasileiras. Compilation film, 80 mins., b \& w. (Available on YouTube at https://www.youtube.com/watch?v=k1j06pYHmiw)

1938 Inspetoria Especial de Fronteiras. Rio de Janeiro: Ministério da Guerra; 99 mins., b \& w. 